\title{
Supported liquid membranes technologies in metals removal from liquid effluents ${ }^{(\bullet)}$
}

\author{
D. de Agreda*, I. Garcia-Diaz*, F.A. López* and FJ. Alguacil*
}

\begin{abstract}
The generation of liquid effluents containing organic and inorganic residues from industries present a potential hazardousness for environment and human health, being mandatory the elimination of these pollutants from the respective solutions containing them. In order to achieve this goal, several techniques are being used and among them, supported liquid membranes technologies are showing their potential for their application in the removal of metals contained in liquid effluents. Supported liquid membranes are a combination between conventional polymeric membranes and solvent extraction. Several configurations are used: flat-sheet supported liquid membranes, spiral wounds and hollow fiber modules. In order to improve their effectiveness, smart operations have been developed: non-dispersive solvent extraction, non-dispersive solvent extraction with strip phase dispersion and hollow fiber renewal liquid membrane. This paper overviewed some of these supported liquid membranes technologies and their applications to the treatment of metal-bearing liquid effluents.
\end{abstract}

\section{Tecnologías de membranas líquidas soportadas en la eliminación de metales de efluentes líquidos}

\begin{abstract}
Resumen
La generación, por parte de las industrias, de efluentes líquidos conteniendo sustancias orgánicas e inorgánicas, es un peligro potencial tanto para los humanos como para el medio ambiente, siendo necesaria la eliminación de estos elementos tóxicos de las disoluciones que los contienen. Para conseguir este fin, se están aplicando diversas técnicas y entre ellas las tecnologías de membranas líquidas soportadas, están demostrando sus aptitudes para la eliminación de metales contenidos en efluentes líquidos. Las membranas líquidas soportadas, resultan de la unión de las membranas poliméricas y de la tecnología de extracción líquido-líquido. Este tipo de membranas se pueden utilizar en diversas configuraciones: plana, módulo en fibra hueca y módulo en espiral y para aumentar su efectividad se están desarrollando las llamadas operaciones avanzadas: extracción no dispersiva, extracción no dispersiva con dispersión de la fase de reextracción y empleo del módulo de fibra hueca, con renovación de la membrana líquida. En este trabajo se revisan estas operaciones de membranas líquidas soportadas y algunas de las aplicaciones de las mismas, en el tratamiento de efluentes líquidos conteniendo metales.
\end{abstract}

Palabras clave Membranas líquidas soportadas; Metales; Agentes de extracción; Líquidos iónicos; Efluentes líquidos; Medio ambiente.

\section{INTRODUCTION}

Chemical and metallurgical industries are the main producers of metal-bearing liquid effluents, that due to the toxic character of many of the metals contained in them, need be treated before final discharge. Thus, industries are increasingly being forced either by the administration, regulatory, cost pressures and social pressures to reduce the amount and environmental sensitivity of the liquid waste they produce.
Several drawbacks of the often known as classical removal or separation technologies reduced the grade of effectiveness in the elimination of metals, principally when the aqueous solution is complex in its composition or when the metal is presented in the liquid solution at very low concentrations.

Because that, technologies as liquid-liquid extraction, liquid membranes and ion exchange, adsorption and bio-adsorption are being used in the

(•) Trabajo recibido el día 24 de Noviembre de 2010 y aceptado en su forma final el día 3 de Febrero de 2011.

* Centro Nacional de Investigaciones Metalúrgicas (CSIC), Avda. Gregorio del Amo, 8, 28040 Madrid (Spain). e-mail corresponding author: fjalgua@cenim.csic.es. 
treatment of liquid effluents, in order to increase selectivity and effectiveness of decontamination.

Among the above, membrane technologies are one of the most important topic in today's research and practical use. Liquid membrane processes have been suggested as a clean technology due to their characteristic of high specificity, high intensity and productivity as well as low emissions and low energy requirements. Moreover, the extraction and stripping steps typical of the other separations technologies, are reduced in liquid membranes to a single step.

Thus, the use of liquid membranes has gained a general interest in the treatment of effluents where solute concentrations are low and large volume solutions must be processed, and if possible, without generating any secondary waste.

There are two types of liquid membranes, unsupported and supported liquid membranes. Nonsupported liquid membranes include: bulk liquid membranes and emulsion liquid membranes, and though they have received a great interest, they are considered not very attractive for practical use due to various problems that they present under operation.

Due to the above, the present paper reviewes recent advances in supported liquid membranes technologies and some of their application in the treatment of metal-bearing liquid effluents.

\section{TOXICITY OF METALS}

The increase of industrial activity is the main responsible of the environmental problems and ecosystem damage associated with the accumulation of pollutants such as toxic metals (chromium, copper, lead, cadmium, zinc, nickel, etc.). Heavy metals are non-biodegradable and are considered to be particularly dangerous pollutants, whereas it is important to note that some metals (in a determined percentage) are essential for both survival and health of human and for natural ecosystems. Thus, and referring to the human health impact, each metal causes different effects and symptoms. Some examples are given below.

Zinc, when present in trace amounts, is considered an essential element for life. It is a component of over 200 enzymes important for immune function and with catalytic and structural roles. Signals of zinc deficiency in human include loss of appetite, growth retardation, skin changes and immunological abnormalities. However, a concentration of zinc higher than the essential can be harmful to health. Symptoms in the case of zinc toxicity are irritability, muscular stiffness, loss of appetite, nauseas and a suppression of immune response $\mathrm{e}^{[1-3]}$.
Among the metals considered as hazardous for living organisms, chromium is recognized to be one of the most dangerous due to its effect on development of cancer and non-cancer diseases. Chromium as essential metal is involved in glucose metabolism and insulin activity. The toxicity of chromium(III) appears to be quite low, the only adverse effects observed in humans have been liver and kidney problems after the ingestion of very high doses ${ }^{[4}$ and 5$]$.

Chromate ion (hexavalent chromium) has been related to an increase incidence of cancer in the digestive tract and lungs $\left.{ }^{[6 \text { and }} 7\right]$. In contact with the skin, this element produces dermatitis ${ }^{[3]}$.

Selenium has structural and enzymatic roles. It is predominantly incorporated in selenoproteins which are vital for normal health and reproduction. It is necessary for immunocompetence; antioxidant function; testosterone metabolism; sperm structure and hence mobility; and a thyroid hormone metabolism. Selenium decreases the risk of cardiomyopathy (Keshan disease) and osteoarthropathy (Kashin-Bek disease) ${ }^{[3}$ and 8 ]. Chronic selenium toxicity in humans results in selenosis ${ }^{[5]}$, characterized by hair loss, fingernails changes and brittleness, gastrointestinal disturbance, skin rash, garlic breath, and abnormal functioning of the nervous system. Other toxic effects of selenium are a disruption of endrocrine function, synthesis of thyroid hormones and growth hormones, an insulinlike growth factor metabolism and leucopenia.

Iron is an essential element for humans. It is a constituent of hemoglobin, myoglobin and different enzymes. The deficiency of iron results in anemia. The accidental ingestion of high concentration of iron is characterized by vomiting and diarrhea with subsequent effect on the cardiovascular and central nervous system, kidney, liver and blood ${ }^{[5]}$.

As another example, copper is an essential component of many proteins, enzymes and coenzymes. Copper deficiency results in hematological deficiencies, anemia, neutropaenia and thrombocytopaenia, skin depigmentation and other effects $^{[3}$ and 5].

Very high levels of copper can cause acute toxicity. It is know that human death can occur from deliberate ingestion of large quantities of copper sulfate. Copper consumption in high doses brings about serious toxicological concerns since it can be deposited in the brain, skin, liver, pancreas, myocardium $^{[9]}$, initiates intestinal distress, kidney damage and anemia ${ }^{[10]}$.

Molybdenum is considered an essential element due to its role in several enzymes involved in hydroxylation reactions. There is no well described deficiency syndrome in humans. Molybdenum toxicity causes a physcological copper deficiency. Respiratory symptoms may occur by fume inhalation ${ }^{[3]}$. 
Manganese is needed for carbohydrate metabolism and has and antioxidant role as a component of mitochondrial. Deficiency signs include poor reproductive performance, growth retardation, congenital malformations in offspring, abnormal function of bone and cartilage, and impaired glucose tolerance. Toxicity to humans is manifested by a psychologic and neurologic disorder, termed manganism, which closely resembles Parkinson's disease. Both manganism and Parkinson's disease involve alterations of neurotransmitter systems, and are irreversible processes ${ }^{[5]}$.

The toxicological character of nickel to humans is related to that the ingestion of this element, both in soluble and non-soluble forms, is consistently associated, among other, with lung, nasopharyngeal cancer and kidney problems aside from gastrointestinal distress, pulmonary fibrosis and skin dermatitis ${ }^{[11]}$.

Lead has been cited as one of the three most toxic heavy metals that have latent long-term negative impacts on the health, causing anemia, encephalopathy, hepatitis and nephritic syndrome ${ }^{[12]}$.

Cadmium also exposes human health to severe risks, as it can provoke cancer, kidney damage, mucous membrane destruction, vomiting, diarrhea and bone damage as well as affect the production of progesterone and testosterone ${ }^{[13]}$.

Among other metals, arsenic, mercury and aluminium are considered as toxic for humans.

\section{SUPPORTED LIQUID MEMBRANES}

Supported liquid membranes are based on the use of a porous solid membrane (polymeric or ceramic) which supports or hold the organic phase and separates the feed and the stripping aqueous solutions. The pores of the solid membrane are completely filled, by capillarity, with the organic or carrier phase and this impregnation process makes relatively stable and heterogeneous solid-liquid membranes. Often, the solid supports are hydrophobic in nature, which facilitates wetting by the organic solution and the reject of the aqueous phases. Membrane wetting time by the organic phase ranges from a few minutes to several hours.

The supported liquid membranes operational modes frequently used are thin flat-sheet supports, hollow fibers and spiral wound modules, the characteristics of which can be found elsewhere ${ }^{[14]}$.

At present, there are few, if any, large scale operations of supported liquid membranes basically due to their apparent lack of stability under longterm operation. Normally, this decreasing in stability is due to the loss of the organic phase filling the membrane pores. Besides, there are other possibilities, such as the characteristics of the solid membrane support and organic solutions. The major degradation causes can be summarized as ${ }^{[15]}$ :

- Pressure difference over the membrane.

- Solubility of species from the feed and strip phases and organic-membrane phase.

- Blockage of the membrane pores by precipitation of metal-carrier complex in the pores.

- Progressive wetting of the pores in the membrane support by both aqueous phases, causing the displacement of the organic phase filling the membrane pores.

- Possibility of emulsion formation in the organic phase.

Among others, the loss of membrane stability is observed by a decreasing in the membrane permeation coefficient or the membrane flux, and to avoid this undesiderable situation several approaches are proposed, such as:

- Development of dispositives for membrane refilling with fresh organic solution once the supported liquid membrane is loosing its properties,

- Sandwich type membranes, in which a small reservoir of the organic solution is placed between two or more supports (Fig. 1),

- Gelation of SLMs, a gel is formed to avoid the flowing of the organic phase away from the gelled membrane,

- Polymer inclusion membranes, in which the solid support is created with the carrier phase included within,

- Stabilization of the solid support by plasma polymerization surface coating,

- Other smart supported liquid membranes technologies, though not essentially supported liquid membranes in themselves, they use a solid microporous barrier to separate the aqueous phases from the organic solution. Included in this concept are: non-dispersive solvent extraction (NDSX), pseudo-emulsion hollow fiber strip dispersion (PEHFSD) and hollow fiber renewal liquid membrane (HFRLM) technologies.

\subsection{Smart Supported Liquid Membrane Technologies}

\subsubsection{Non-dispersive solvent extraction (NDSX)}

In non-dispersive solvent extraction technology with single hollow fiber module (Fig. 2), the aqueous 


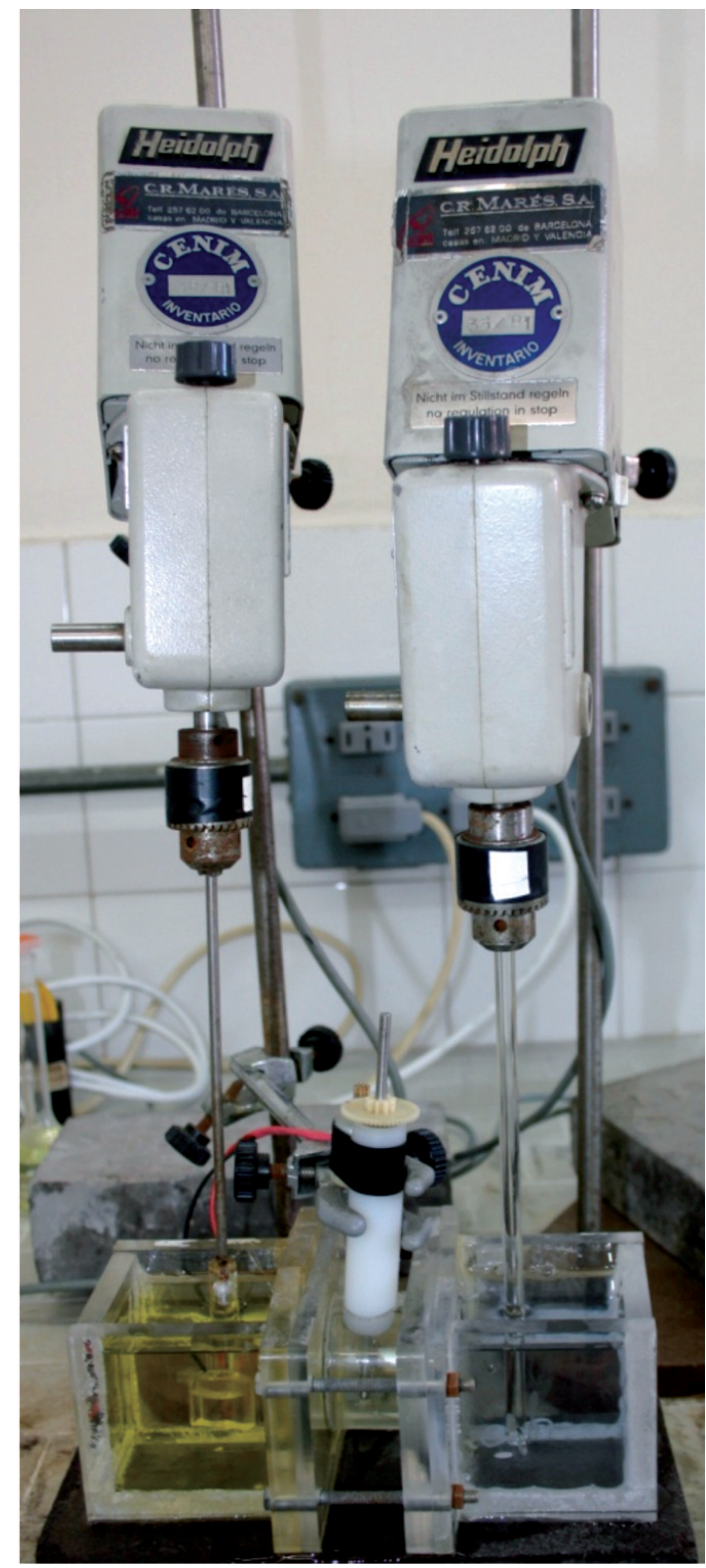

Figure 1. View of a sandwich-membrane type cell. Left hand compartment is for the feed solution, middle compartment is for the organic solution, right hand compartment is for the stripping solution. Two solid supports are located between the feed and organic and the organic and stripping phases compartments, respectively. The three compartments are stirred in order to homogenize the respective bulk solutions.

Figura 1. Celda para membranas en configuración tipo sándwich. Compartimiento izquierdo: fase de alimentación, compartimiento central: fase orgánica, compartimiento de la derecha: disolución de reextracción. Dos soportes sólidos están colocados entre los compartimentos de alimentación orgánica y reextracción, respectivamente. Las fases están agitadas para su correcta homogeneización. and organic phases are contacted co- or countercurrently in the module for carrying out extraction or stripping runs, either in recirculation or one through modes. In the extraction module, the feed solution flows through the tube side of the fibers, whereas the organic phase circulates through the shell side, wetting the wall of the fibers. In the stripping module, the metal-loaded organic phase flows through the shell side, whereas the stripping solution flows through the tube side. Then, the metal-free organic solution is recirculated to the first or extraction module. For the correct maintaining of the interface, the pressure of the aqueous phases is typically held $0.2-0.5 \mathrm{bar}$ higher than the pressure in the organic phase.

In dual function modules, the extraction and stripping of the metal are carried out simultaneously in a single hollow fiber module containing one set of fibers for extraction and another set for stripping.

\subsubsection{Non-dispersive solvent extraction with strip phase dispersion (NDSXSD)}

The hollow fiber strip dispersion process comprises a single module for extraction and stripping (Fig. 3). A pseudo-emulsion phase is prepared in a stirred tank, this pseudo-emulsion is formed by the organic solution and the dispersed stripping solution. Once pumped to the module for the shell side, the organic phase wets the porous wall of the fiber because of its hydrophobic nature. The feed solution is fed into the module through the tube side of the fibers. The differential pressure is always kept below the breakthrough pressure, thus in the feed phase the pressure is maintained in the $0.2-0.5$ bar range higher than in the pseudo-emulsion phase. The characteristics of the pseudo-emulsion should be such that it should have clear and fast (in the order of a few minutes) phase separation when mixing in the tank is stopped (Fig. 4). Then the recovery of the metal from the stripping solution can be achieved.

Recently, this technology had been implemented in a flat-sheet configuration and cell operational mode for the transport of chromium(VI) from acidic solutions using the tertiary amine Hostarex A327 as carrier and $\mathrm{NaOH}$ solutions as strippant ${ }^{[16]}$.

\subsubsection{Hollow fiber renewal liquid membrane (HFRLM)}

In this technology, the stirred mixture of organic phase and feed phase (or stripping phase) is pumped 


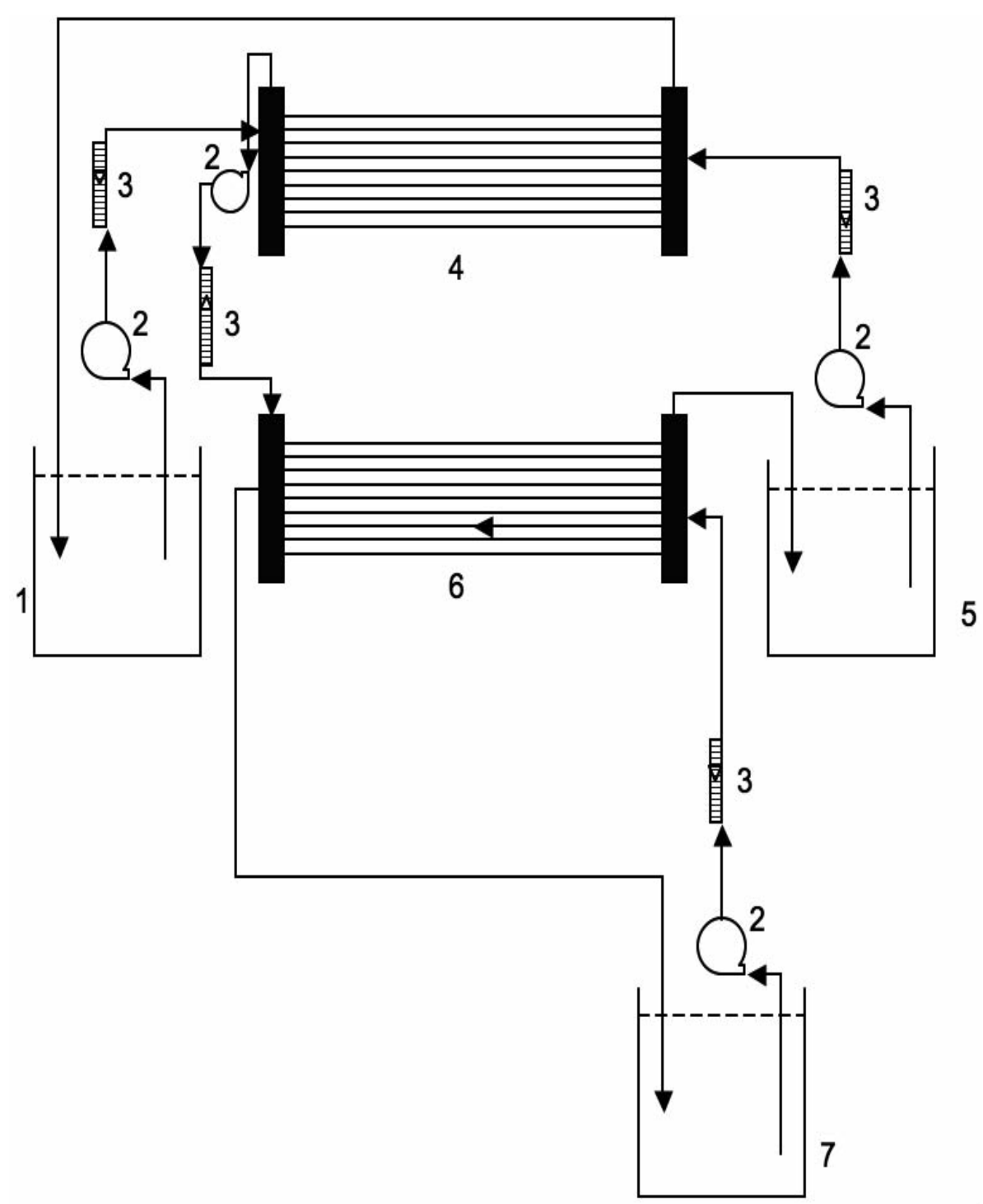

Figure 2. A schematic view of an integrated NDSX membrane process using two hollow fiber contactors. (1) feed phase reservoir tank, (2) pumps, (3) flow-meters, (4) extraction module, (5) organic phase reservoir tank, (6) stripping module, (7) strip phase reservoir tank. Operation in counter-current and recirculation of the solutions.

Figura 2. Esquema de un proceso integrado de extracción no dispersiva usando dos modulos de fibra hueca. (1) depósito conteniendo la fase de alimentación, (2) bombas, (3) caudalimetros, (4) modulo de extracción, (5) depósito conteniendo la disolución orgánica, (6) modulo de reextracción, (7) depósito conteniendo la disolución de reextracción. Operación en contracorriente y recirculación de todas las disoluciones.

through the tube side of the fibers, the organic phase is uniformly dispersed in the corresponding aqueous solution and wets and fills the pores of the module (Fig. 5). The stripping phase (or the feed phase) flows through the shell side, co- or countercurrently. The flows are controlled to maintain a positive pressure on the shell side, in order to prevent penetration of the organic phase into the shell side.

\section{CARRIERS IN ORGANIC PHASES AND IONIC LIQUIDS}

The organic phase is formed by an organic diluent, which is non-miscible in water, and dissolved the carrier which is the active substance in the metal transport process. At first, it is accepted that the organic diluent does not take part or has no influence 


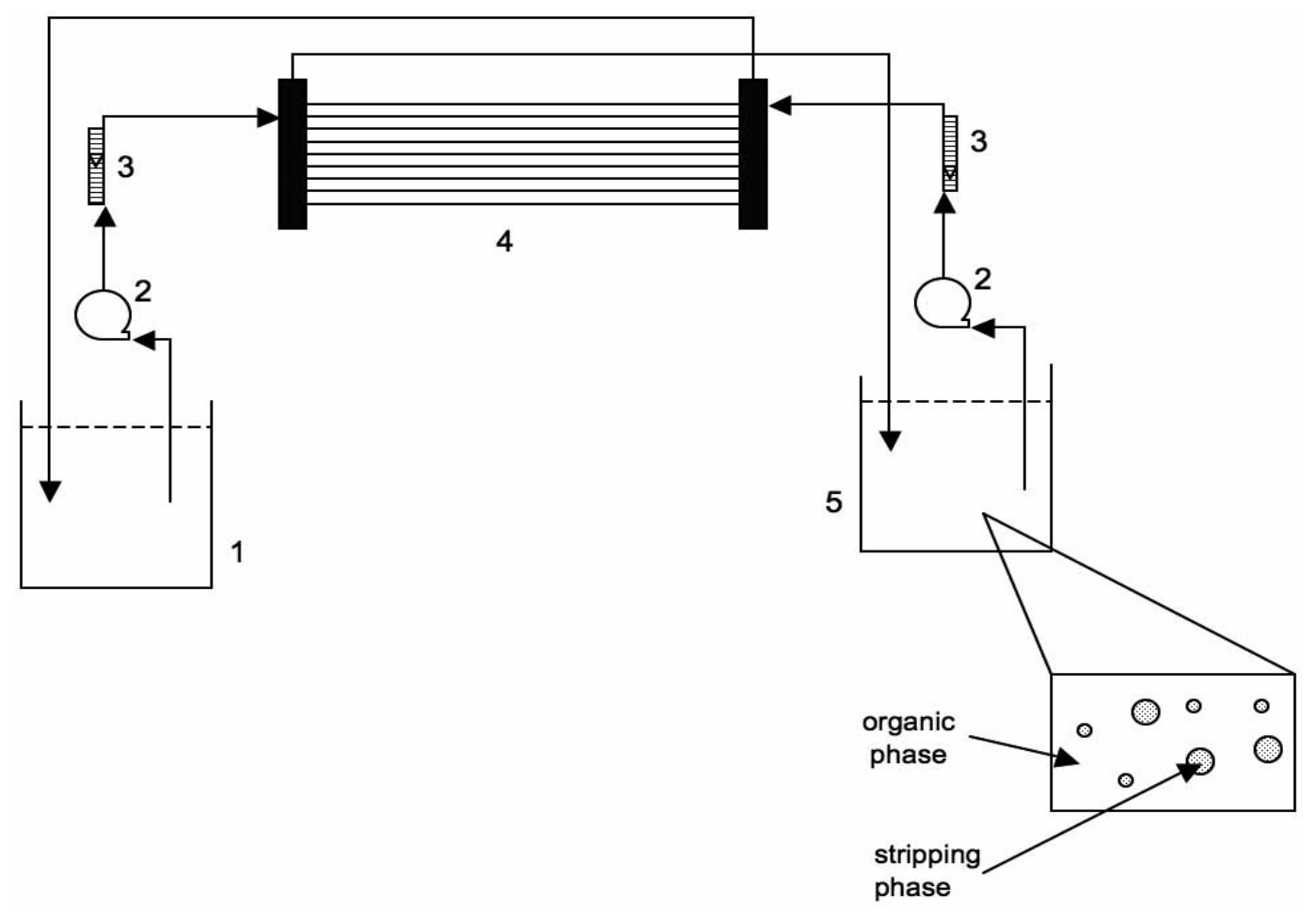

Figure 3. Schematic view of non-dispersive solvent extraction with strip dispersion process using a hollow fiber module. (1) feed phase reservoir tank, (2) pumps, (3) flowmeters, (4) hollow fiber module, (5) pseudo-emulsion phase reservoir tank. Operation in counter-current and recirculation of the phases.

Figura 3. Esquema de un proceso de extracción no dispersiva, con dispersión de la fase de reextracción empleando un modulo de fibra hueca. (1) depósito de la fase de alimentación, (2) bombas, (3) caudalimetros, (4) modulo de fibra hueca, (5) depósito de la fase de pseudo-emulsion. Operación en contracorriente y recirculación de las fases.

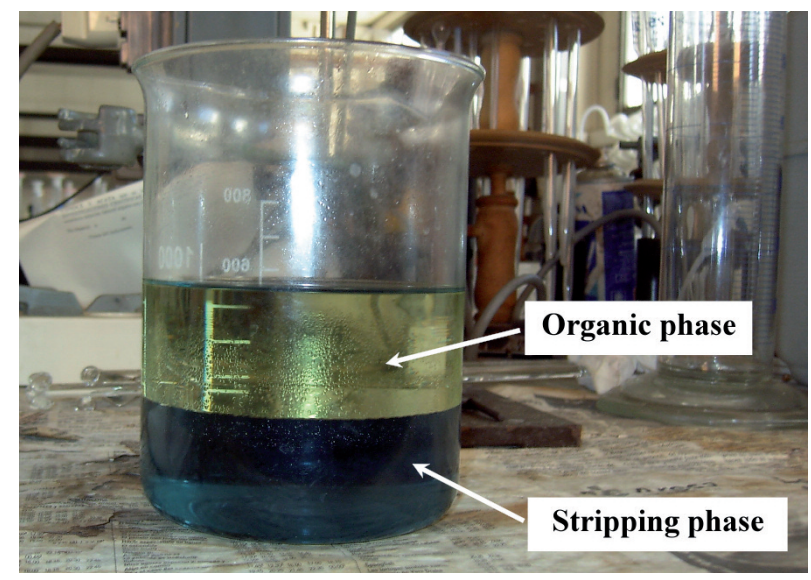

Figure 4. Detail of the pseudo-emulsion phase reservoir tank at the end of the operation and once the two phases are completely separated.

Figura 4. Detalle del depósito conteniendo la pseudo-emulsión, una vez finalizada la operación y con las dos fases completamente separadas. in the transport process, but this rule is sometimes far from reality and in fact the properties of the diluents can determine the results and performance, with respect to metal transport, of a given organic solution. Normally, diluents used in membrane transport are the same as those used in liquid-liquid extraction technology, which in many cases are aromatic or aliphatic petroleum fractions.

Extractants in liquid-liquid extraction terminology or carriers in membrane terminology are, of course, organic compounds. During all these years, carriers are becoming increasingly selective, allowing the specific separation of some solutes from another. The carriers employed in supported liquid membranes are nearly the same as the extractants used in liquidliquid extraction, though due to the characteristics of supported liquid membranes technology some specific or more expensive carriers can be used for metal transport in membrane operation. Some of the extractants or carriers that are available commercially are summarized in table I. 


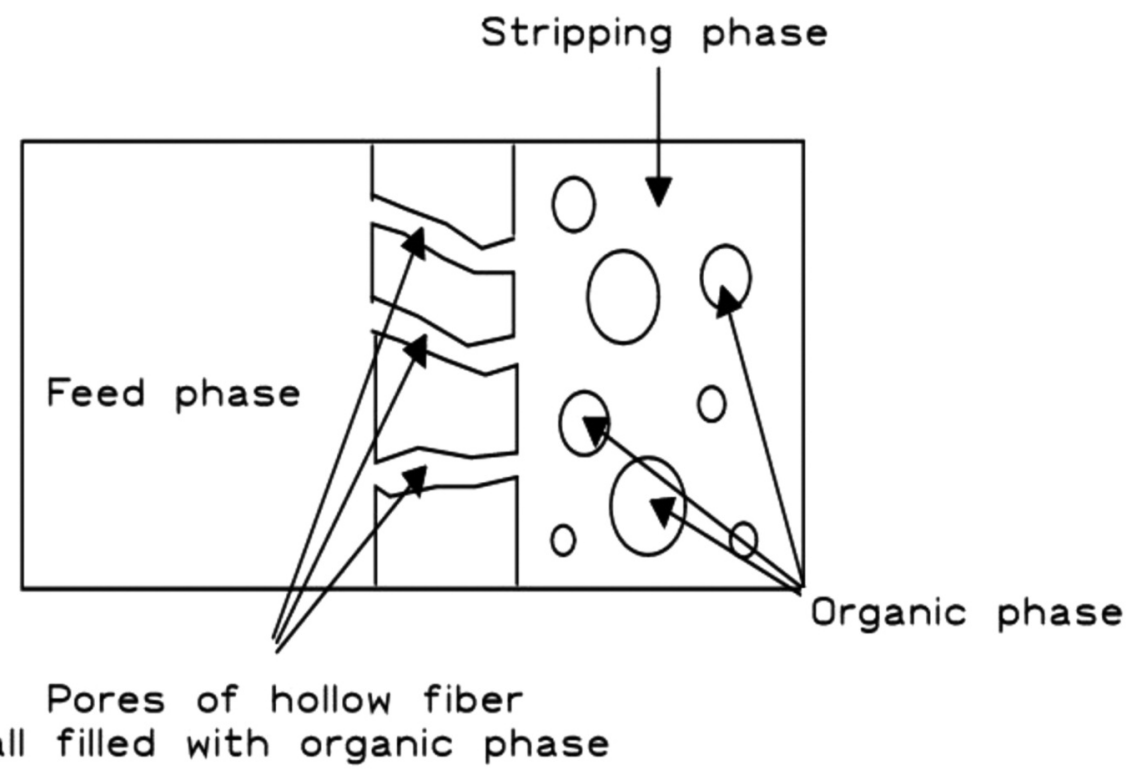

Figure 5. Schematic view of HFRLM operation with organic phase dispersion and formation of a pseudo-emulsion between the organic and strip solutions.

Figura 5. Esquema de la operación en un módulo de fibra hueca y renovación de la membrana líquida, mediante dispersión de la fase orgánica y formación de una pseudo-emulsión, entre esta fase y la fase de reextracción.

Considering the type of reaction responsible of metal extraction or transport, carriers can be broadly classified as: i) ACIDIC TYPE REAGENTS. They extract metals by a cationic exchange reaction: where HR is the extractant. This type of extractants

$$
M_{a q}^{n+}+n H R_{\text {org }} \Leftrightarrow M R_{n o r g}+n H_{a q}^{+}
$$

can be further divided into two sub-types, namely, non-chelating and chelating extractants.

Non-chelating acid reagents are divided also into two types: organic derivatives of phosphorous acids and carboxylic acids. The former includes esters of phosphoric, phosphonic and phosphinic acids, and similar compounds containing polyfunctional groups, the most versatile of all of them being di (2 ethylhexyl)phosphoric acid, commonly known as DEHPA. The other type of non-chelating extractants include the synthetically produced Versatic acids, and naphtenic acids obtained from the distillation of crude petroleum.
Chelating reagents are those containing a group with an easily dissociated proton which is nearby a donor group capable of forming bidentate complexes with metal ions. At present, the most used extractans of this type are ketoximes, salicylaldoximes or mixtures. For investigations carried out in ammoniacal medium $\beta$-diketones derivatives are also being used.

ii) BASIC OR ANIONIC TYPE REAGENTS. This type of carriers, extract or transport anionic metal complexes by an anionic exchange reaction:

$$
M X_{y_{\text {aq }}}^{a-}+a\left(R N H_{3}^{+} X^{-}\right)_{\text {org }} \Leftrightarrow\left(R N H_{3}^{+}\right)_{a q} M X_{y_{\text {org }}}^{a-}+a X_{a q}^{-}
$$

In order to achieve this exchange, the amine must be first converted to the amine salt to provide the anion to exchange with the metal species: 
Table I. Selected liquid-liquid extractants used for metal transport studies

Tabla I. Algunos agentes de extracción empleados en el transporte de metales

\begin{tabular}{|c|c|c|}
\hline Type & Active substance & Trade name \\
\hline \multicolumn{3}{|l|}{ Acidic extractants } \\
\hline \multirow[t]{2}{*}{ - phosphoric acids } & mono-2-ethylhexylphosphoric acid & M2EHPA \\
\hline & di-2-ethylhexyl phosphoric acid & D2EHPA,DP-8R,TOPS-99 \\
\hline — phosphonic acid & $\begin{array}{l}\text { 2-ethylhexylphosphonic acid-mono- } \\
\text { 2-ethylhexyl ester }\end{array}$ & PC-88A \\
\hline \multirow[t]{2}{*}{ — phosphinic acids } & $\begin{array}{l}\text { di-2,4,4-trimethylpentyl phosphinic } \\
\text { acid }\end{array}$ & Cyanex 272 \\
\hline & $\begin{array}{l}\text { di-2,4,4-trimethylpentyl } \\
\text { dithiophosphinic acid }\end{array}$ & Cyanex 301 \\
\hline \multirow{4}{*}{$\begin{array}{l}\text { - hydroxybenzophenone } \\
\text { oximes }\end{array}$} & 5-dodecylsalicylaldoxime & LIX 860 series, LIX 622 \\
\hline & 5-nonilsalicylaldoxime & $\begin{array}{l}\text { Acorga P50 and P5000 } \\
\text { series, Acorga PT5050, } \\
\text { Acorga M5640 }\end{array}$ \\
\hline & $\begin{array}{l}\text { 2-hydroxy-5-nonylacetophenone } \\
\text { oxime }\end{array}$ & LIX 84 \\
\hline & $\begin{array}{l}\text { mixtures of ketoximes and } \\
\text { salicylaldoximes }\end{array}$ & LIX 984 \\
\hline$-\beta$-diketones & & LIX 54 \\
\hline \multicolumn{3}{|l|}{ Basic extractants } \\
\hline \multirow[t]{2}{*}{ - primary amines } & $\begin{array}{l}\text { terc-alkylamine (isomers mixture in } \\
\text { the } C_{12}-C_{14} \text { range) }\end{array}$ & Primene $81 \mathrm{R}$ \\
\hline & $\begin{array}{l}\text { terc-alkylamine (isomers mixture in } \\
\text { the } \mathrm{C}_{16}-\mathrm{C}_{22} \text { range) }\end{array}$ & Primene JMT \\
\hline \multirow[t]{2}{*}{ - secondary amines } & $\begin{array}{l}\mathrm{N} \text {-dodecyl-1,1,3,3,5,5- } \\
\text { hexamethylhexylamine }\end{array}$ & Amberlite LA2 \\
\hline & tri-octylamine & \\
\hline \multirow[t]{3}{*}{ — tertiary amines } & tri-isooctylamine & Alamine 336 \\
\hline & $\begin{array}{l}50 \% \text { mixture of tri-octylamine and } \\
\text { tri-decylamine }\end{array}$ & $\begin{array}{l}\text { Hostarex A324 } \\
\text { Hostarex A327 }\end{array}$ \\
\hline & tridodecylamine & Alamine 304 \\
\hline $\begin{array}{l}\text { - quaternary ammonium } \\
\text { salts }\end{array}$ & tri-octylmethylammonium chloride & Aliquat 336 \\
\hline \multicolumn{3}{|l|}{ Solvation extractants } \\
\hline - phosphoric esters & tri-n-butylphosphate & TBP \\
\hline — phosphonic esters & dibutylbutylphosphonate & DBBP \\
\hline \multirow[t]{2}{*}{ — phosphine oxides } & tri-n-octylphosphine & Cyanex 921 \\
\hline & mixture of phosphine oxides & Cyanex 923 \\
\hline — phosphine sulphides & tri-isobutylphosphine sulphide & Cyanex 471X \\
\hline
\end{tabular}




$$
R N H_{2_{\text {org }}}+H_{a q}^{+}+X_{a q}^{-} \Leftrightarrow R N H_{3}^{+} X_{\text {org }}^{-}
$$

This last reaction can occur in the same extraction step of the metal itself, if suitable acidity to form the amine salt is available in the aqueous solution, or in a step prior to metal extraction. Then, the usefulness of amines as carriers depends basically on the transformation of the amine to an amine salt and the ability of metals to form anionic species in aqueous media. In eqs. (2) and (3), $\mathrm{X}$ represents the counter-ion for $\mathrm{M}^{\mathrm{n}+}, \mathrm{H}^{+}$or the cationic ammonium ion.

However, in some cases amines can extract metallic neutral species by donation of a free electronpair of the nitrogen atom:

$$
R \mathrm{NH}_{2_{\text {org }}}+\mathrm{Fe}_{2}\left(\mathrm{SO}_{4}\right)_{3_{\text {aq }}} \Leftrightarrow R \mathrm{NH}_{2} \cdot \mathrm{Fe}_{2}\left(\mathrm{SO}_{4}\right)_{3_{\text {org }}}
$$

In practice, basic extractants or carriers are limited to amines and quaternary ammonium salts, though recently a guanidine derivative named LIX 79 has been used to transport gold(I) and silver(I) from alkaline cyanide media.

\section{iii) NEUTRAL OR SOLVATION TYPE} REAGENTS. These extractants are based on the solvation of neutral inorganic molecules or complexes by electron-donor atoms contained in the extractant molecule. By means of this solvation, the solubility of inorganic species in the organic solution is increased.

Two main sub-types of extractants can be considered here: organic compounds containing oxygen bonded to a carbon atom, and extractants containing oxygen or sulphur bonded to phosphorous atoms. The major difference between these two types of extractants is the role of water in the extraction or transport process. The more polar phosphorous derivatives compete favourably with water and can replace this molecule in the primary coordination sphere of metallic compounds. In the former case, compounds with an oxygen atom bonded to a carbon atom, water is a necessary part of the complex, probably due to the formation of hydrogen bonding-bridges between the organic and metal moieties of the given complex.

As a general rule, it is very difficult to give a reaction which can be representative of metal extraction by these reagents, some examples being:

$$
\begin{gathered}
\mathrm{M}_{\mathrm{aq}}^{+}+\mathrm{Au}(\mathrm{CN})_{2_{\mathrm{aq}}}^{-}+n L_{\text {org }} \Leftrightarrow \operatorname{MAu}(\mathrm{CN})_{2} \cdot L_{n_{\text {org }}} \\
\mathrm{H}_{\text {aq }}^{+}+\mathrm{HCrO}_{4_{\text {aq }}}^{-}+n L_{\text {org }} \Leftrightarrow \mathrm{H}_{2} \mathrm{CrO}_{4} \cdot L_{n_{\text {org }}} \\
\mathrm{H}_{3} \mathrm{AsO}_{4_{\text {aq }}}+\mathrm{H}_{2} \mathrm{SO}_{4_{\text {aq }}}+n L_{\text {org }}+6 \mathrm{H}_{2} \mathrm{O} \Leftrightarrow\left(\mathrm{H}_{3} \mathrm{AsO}_{4} \cdot \mathrm{H}_{2} \mathrm{SO}_{4} \cdot 6 \mathrm{H}_{2} \mathrm{O} \cdot \mathrm{L}_{n}\right)_{\text {org }}
\end{gathered}
$$

where L represents a given neutral extractant.

Carriers in which oxygen is bonded to a phosphorous atom are grouped in three sub-types: phosphate esters, phosphonic esters or phosphonates, and phosphine oxides. In the case of neutral reagents in which a sulphur atom is bonded to phosphorous, only one compound has been marketed with the name Cyanex 471X, whose active substance is a trialkylphosphine sulphide $\left(\mathrm{R}_{3} \mathrm{PS}\right)$.

Extractants containing carbon-oxygen bonds are essentially ethers, ketones, esters and alcohols.

Other potential carriers for metal transport include amides, alkelenephosphine dioxides, calixarenes, thiourea derivatives, phospholene derivatives and ionic liquids, the latter being considered separately.

In all the above reactions (eqs. (1-7)), M represents a given metal, and the subscripts aq and org refer to the aqueous and organic phases, respectively.
Ionic liquids (ILs) or room-temperature ionic liquids (RTILs) are a new generation of extractants, considered as non-aggressive compounds with environment ("Green Chemistry"), and thus they are nicknamed as "Green Solvents", which have been proposed for metal separation process. The adopted classification in order to distinguish between ionic liquids and melt salts is that ionic liquids are liquids under $100^{\circ} \mathrm{C}$ and melt salts are liquid over $100^{\circ} \mathrm{C}$.

Ionic liquids are formed by a nanosymmetrical or unsymmetrical organic cation such as imidazolium, $\mathrm{N}$-alkylpyridinium, alkylphosphonium, etc. (Fig. 6 ), and different inorganic or organic anions such as halides, nitrate, tetrafluoroborate $\left(\left[\mathrm{BF}_{4}^{-}\right]\right)$, trifluoromethylsulfonate $\left(\left[\mathrm{OTf}^{-}\right]\right)$, bis(trifluoromethanesulfonyl)imide $\left(\left[\mathrm{NTf}_{2}{ }^{-}\right]\right)$, etc.

These compounds were mostly developed and investigated from the 90's, since they exhibit 


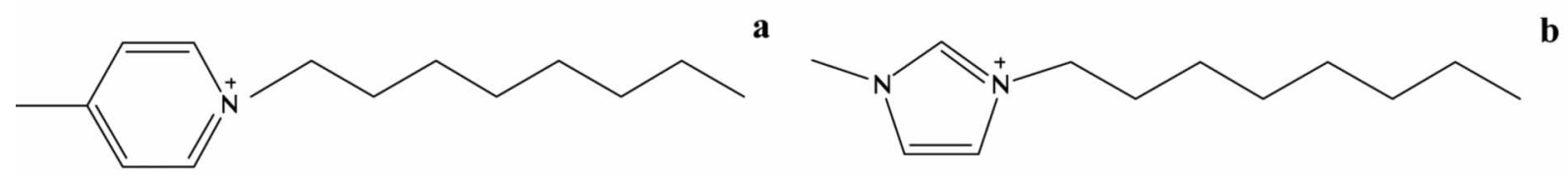

Figure 6. Ionic liquids. a) 1-octyl-4-methylpyridinium cation, b)1-octyl-3-methylimidazolium cation.

Figura 6. Liquidos iónicos. a) catión 1-octil-4-metylpiridinio, b) catión 1-octil-3-metilimidazolio.

unique properties compared to other solvents. The ionic liquids are generally colorless liquids with relatively high viscosities. The exhibit very low vapour pressures under ambient conditions and thus are effectively non-volatile. ILs are good solvents for a broad spectrum of inorganic, organic and polymeric materials and are immiscible with numerous organic solvents. Some properties, such as the thermal stability and miscibility, mainly depend on the anion, while others, such as the viscosity, surface tension and density, depend on the length of the alkyl chain in the cation and/or shape or symmetry ${ }^{[17]}$. These characteristics make these reagents suitable for a broad spectrum of uses such as catalytic reactions, organic synthesis, polymer chemistry, fungicides and electrochemical applications ${ }^{[18-22]}$; recently, they had been proposed as extractants in solvent extraction and ionic exchange technologies, in order to extract metals from metal-bearing wastewaters ${ }^{[23-26]}$.
However, the use of ionic liquids as extractants for metals and other applications is sometimes inefficient, i.e. in removing pollutants from metal-bearing wastewaters. Therefore, task-specific ionic liquids (TSILs) have been developed to avoid these problems. TSILs are ionic liquids with specific functional groups linked by covalent bond to the anionic or, more often, cationic part of the salt (Fig. 7).

Very often, ILs and TSILS are used mixed with other conventional extractants in order to increase the efficiency of the extraction process. Furthermore, this new branch of reagents can extract anions and cations without using ion exchange but with ion pair mechanism.

Applications of ILs and/or TSILs in the removal of metals using supported liquid membrane technologies are very rare; the use of some of these reagents in the separation of metals iron(III), and chromium(VI)) from various aqueous media has been recently reported in the literature (Fig. 8) [27 and 28].<smiles>Cn1cc[n+](CCC/N=C/c2ccccc2O)c1</smiles><smiles>Cc1cc[n+](CCCC#N)cc1</smiles><smiles>CSCC(CCC[N+]1(C)CCCCC1)SC</smiles>

Figure 7. Task selective ionic liquids. a)1-salicylaldehyde-derived-4-methylimidazolium cation, b) 1-butyronitrile-4-methylpyridinium cation, c) 1-methyl-1-[4,5-bis(methylsulfide)] pentylpiperidinium cation.

Figura 7. Liquidos iónicos selectivos. A) catión 1-salicilaldoxima-4-metilimidazolio, b) catión 1butironitril-4-metilpiridinio, c)catión 1-metil-1-[4,5-bis(metilsulfuro)] pentilpiperidinio. 


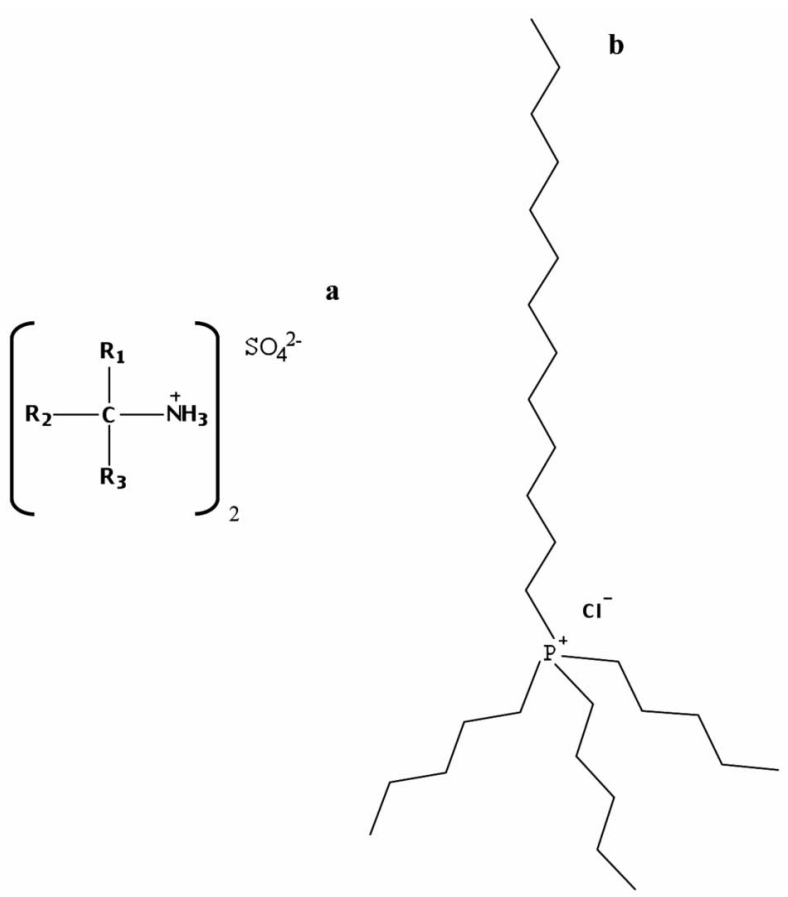

Figure 8. Structures of the ionic liquids used in metal transport studies using smart supported liquid membranes systems. A) ionic liquid derived from the primary amine Primene JMT for the transport of $\mathrm{Fe}$ (III) $\left(\mathrm{R}_{1}, \mathrm{R}_{2}, \mathrm{R}_{3}\right.$ are alkyl chains). B) CYPHOS IL101 ionic liquid for the transport of $\mathrm{Cr}(\mathrm{VI})$.

Figure 8. Estructuras de los liquidos iónicos, empleados en el transporte de metales mediante el uso de técnologias avanzadas, basadas en las membranas líquidas soportadas. A) líquido iónico derivado de la amina primaria PJMT (transporte de $\mathrm{Fe}(\mathrm{III})$ ). B) Liquido iónico CYPHOS IL 101 (transporte de Cr(VI)).

\section{TYPES OF TRANSPORT IN SUPPORTED LIQUID MEMBRANES}

Two main types of transport can be considered in the use of SLMs technologies for metal removal from aqueous solutions:

i) Counter-transport. The transport of the metal contained in the feed solution and the counter-ions, contained in the strip solution, is carried out in opposite directions. The driving force for the metal transport is the difference in the counter-ion concentrations between feed and stripping phases (Fig. 9). This type of transport is typical of cationic exchangers extractants and quaternary ammonium salts.

ii) Co-transport. The transport of the metal and co-ions is carried out in the same direction. In this

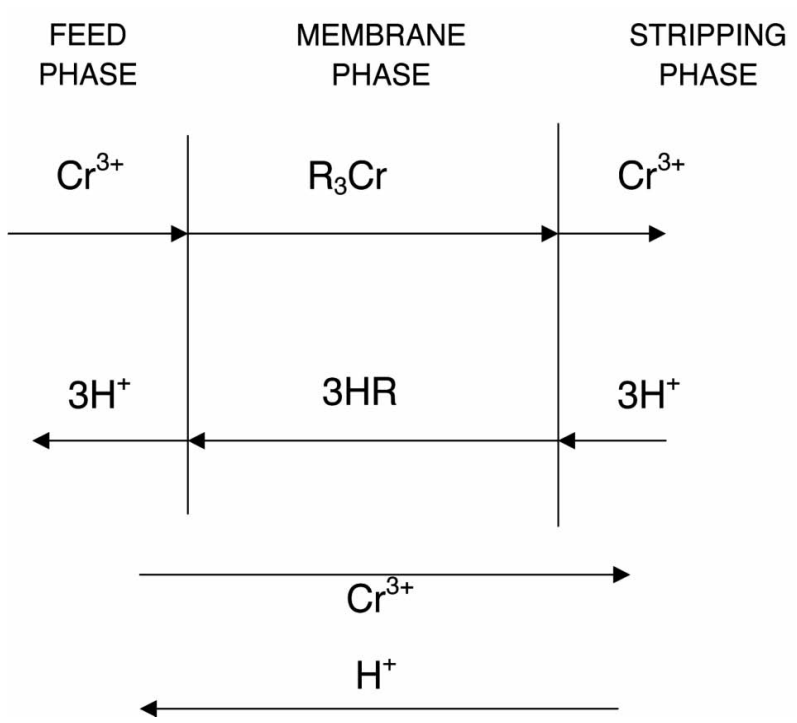

Figure 9. Schematic view of the countertransport mechanism. HR: cationic carrier.

Figura 9. Esquema del mecanismo de contratransporte. HR: agente de extracción ácido.

case, the driving force for metal transport is the difference of concentrations of the co-ion between the feed and stripping solutions (Fig. 10). Cotransport mechanism is common for basic and solvation extractants.

In many applications, the metal is transported against its concentration gradient due to the driving force accompanying the metal transport.

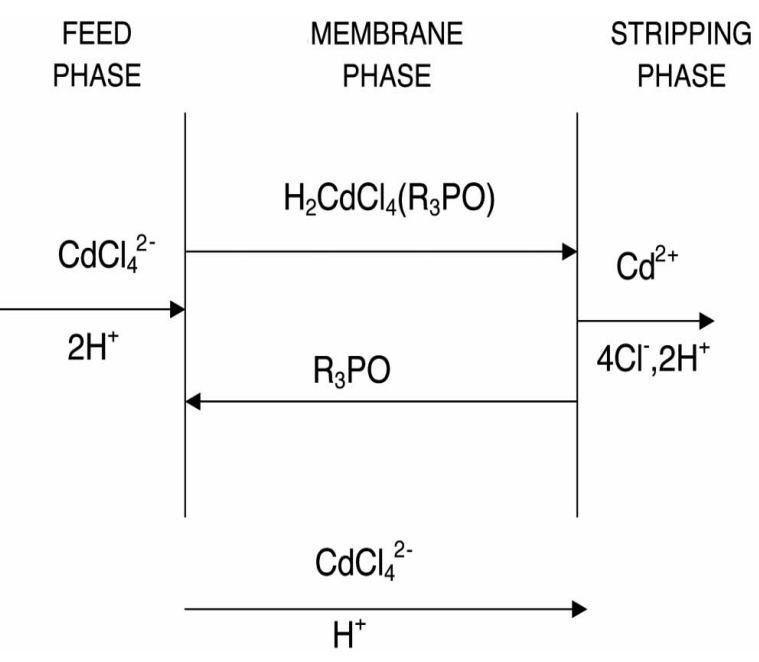

Figure 10. Schematic view of the co-transport mechanism. $R_{3} P O$ : phosphine oxide.

Figura 10. Esquema del mecanismo de co-transporte. $R_{3} P O$ : óxido de fosfina. 
Very often, the transport mechanism consists in a diffusion process combined with a chemical reaction, and several steps are considered (Fig. 11):

i) solute diffusion to the diffusion layer of feed phase,

ii) chemical reaction between the metal species and the carrier in the feed/membrane phases interface,

iii) the metal-carrier complex diffuses through the membrane to the membrane/stripping phases interface,

iv) chemical reaction with the stripping reagent in which the metal-carrier complex is broken-down and the metal is liberated into the stripping phase, at the same time the carrier is regenerated,

v) the stripped metal diffuses to the bulk of the stripping solution and,

vi) the regenerated carrier diffuses through the membrane to the feed/membrane phases interface when the transport process is repeated.

\section{MODELIZATION IN SUPPORTED LIQUID MEMBRANES TECHNOLOGIES}

Equally important as to knowing the mechanism in which a metal is extracted by a carrier and stripped from a loaded organic phase, modelization of liquid membrane systems is needed in order to design and scale up efficient supported liquid membrane recovery processes.

Very often, the overall mass transfer coefficient of a given supported liquid membrane process is calculated from a simplified model derived by

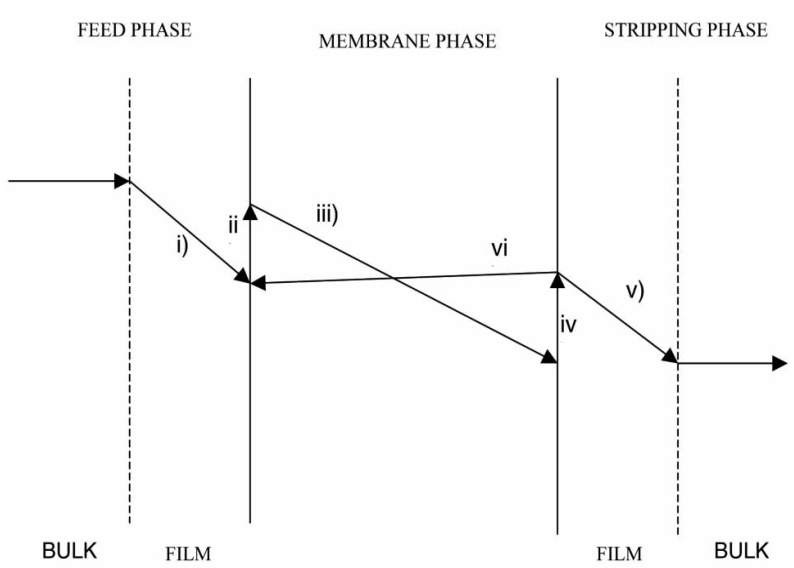

Figure 11. The various steps in the transport of metal species.

Figura 11. Las distintas etapas en el proceso de transporte de un metal.
Danesi ${ }^{[29]}$, in which it is assumed that the organic complex concentration at the interface membrane/ organic phase can be considered negligible, and thus, the transport only depends on the metal concentration in the feed phase, then:

$$
\ln \frac{[\mathrm{M}]_{\mathrm{f}, \mathrm{t}}}{[\mathrm{M}]_{\mathrm{f}, 0}}=-\frac{\mathrm{A}}{\mathrm{V}} \cdot \mathrm{K} \cdot \mathrm{t}
$$

where $[\mathrm{M}]_{\mathrm{f}, \mathrm{t}}$ and $[\mathrm{M}]_{\mathrm{f}, \mathrm{O}}$ are the metal concentrations in the feed phase at an elapsed $t$ and time zero, respectively, $\mathrm{A}$ is the effective membrane area in whatever configuration, $\mathrm{V}$ is the volume of feed solution, $\mathrm{K}$ is the overall mass transfer coefficient and $t$ is the time. Further, and as described below, the overall mass transfer coefficient can be related to the considered individual mass transfer resistances.

On the other hand, and using hollow fiber modules, a modified expression of the above is also useful to evaluate the overall mass transfer coefficient:

$$
V \ln \frac{[M]_{f, 0}}{[M]_{f, t}}=S \cdot t
$$

where $\mathrm{S}$ is a factor dependent on the geometry of the fibers and the module, the linear velocity of the fluids and the overall mass transfer coefficient of the system.

In the case of NDSX operation, the overall mass transfer coefficient is also calculated by using the equations derived for co- or counter-current operational modes ${ }^{[30]}$.

When the metal concentration in the feed solution is high, equations (8) and (9) are no longer valid and the next relationship may be used to evaluate the diffusion coefficient in the organic phase $\left(\mathrm{D}_{\text {org }}\right)$ :

$$
[M]_{f, t}=[M]_{f, 0}-\frac{[L]_{o r g} D_{o r g} A}{n d_{o r g} V} t
$$

where $[\mathrm{L}]_{\text {org }}$ is the carrier concentration in the organic phase, $\mathrm{n}$ is the number of carrier molecules involved in the extraction process and $\mathrm{d}_{\text {org }}$ is the membrane thickness. In hollow fiber operation, a similar expression can be derived in the form: 


$$
[\mathrm{M}]_{\mathrm{f}, 0}=[\mathrm{M}]_{\mathrm{f}, \mathrm{t}}-\frac{[\mathrm{L}]_{\mathrm{org}} \mathrm{k}_{\mathrm{m}} \mathrm{A}}{\mathrm{nV}} \mathrm{t}
$$

where $\mathrm{k}_{\mathrm{m}}$ is the membrane mass transfer coefficient (see below).

In flat-sheet supported liquid membrane modeling it is generally assumed that the mass transfer of a given metal species across the membrane is described only by diffusional parameters since chemical reactions can be considered to occur instantaneously relative to the diffusion processes ${ }^{[31]}$. Then, the flux of the solute crossing the membrane may be derived by applying Fick's first diffusion law to the diffusion layer at the feed side and to the membrane. A final expression, in which the overall mass transfer coefficient is related to the equilibrium and diffusion parameters involved in the metal transport process is consequently derived in the form:

$$
\frac{1}{\mathrm{~K}}=\Delta_{\mathrm{aq}}+\frac{\Delta_{\mathrm{m}}}{\mathrm{C}}
$$

where $\Delta_{\text {aq }}$ and $\Delta_{\mathrm{m}}$ are the transport resistances due to diffusion by the feed boundary layer and through the membrane, respectively, whereas $\mathrm{C}$ is a factor which includes all the equilibrium parameters involved in the transport process ${ }^{[32-34]}$.

In a recent publication ${ }^{[35]}$, it was reviewed the various approaches to the mathematical modeling of liquid membrane separation processes in hollow fiber contactors.

Besides the simplified model described above, in hollow fiber modules, two different approaches are commonly considered to relate the interfacial concentrations:

i) diffusional-kinetic regime, in which the chemical reaction of the extraction process is considered to be fast and, thus, the equilibrium is reached instantaneously. The mass transport resistances only influence the global rate of the transport process.

ii) mixed-kinetic regime, wherein the chemical reaction of the extraction process is not fast and, thus, the global rate of the process depends on both the reaction kinetics and the mass transport.

In case i), the overall mass transfer coefficient is related to the individual mass transfer resistances by:

$$
\frac{1}{\mathrm{~K}}=\frac{1}{\mathrm{k}_{\mathrm{i}}}+\frac{\mathrm{r}_{\mathrm{i}}}{\mathrm{r}_{\mathrm{lm}} \mathrm{K}_{\mathrm{m}}}+\frac{\mathrm{r}_{\mathrm{i}}}{\mathrm{r}_{\mathrm{o}} \mathrm{k}_{\mathrm{o}}}
$$

where $\mathrm{k}_{\mathrm{i}}$ and $\mathrm{k}_{\mathrm{o}}$ are the interfacial coefficients corresponding to the inner and outer aqueous boundary layers, $K_{m}$ is the overall membrane mass transfer coefficient or membrane permeability, and $r_{i}, r_{o}$ and $r_{l m}$ are the hollow fiber inner, outer and log mean radii, respectively. The membrane permeability is related to the distribution coefficient (D) of the extraction process for a given system, thus:

$$
\mathrm{K}_{\mathrm{m}}=\mathrm{D} \cdot \mathrm{K}_{\mathrm{m}}
$$

where $\mathrm{k}_{\mathrm{m}}$ is the membrane mass transfer coefficient.

In case ii), the derived equation which related the overall mass transfer coefficient or the overall mass transfer resistance with the individual mass transfer resistances is given by:

$$
\frac{1}{K}=\frac{1}{k_{i}}+\frac{1}{k_{f}}+\frac{d_{i}}{d_{l m} k_{m} D}+\frac{d_{i}}{D_{h} k_{s} D^{\prime}}
$$

where $\mathrm{d}_{\mathrm{i}}$, and $\mathrm{d}_{\mathrm{lm}}$ are the hollow fiber inner and $\log$ mean diameters, respectively, $\mathrm{D}_{\mathrm{h}}$ is the hydraulic diameter and $\mathrm{D}^{\prime}$ is the distribution coefficient of the stripping process; on the other hand, $\mathrm{k}_{\mathrm{f}}$ and $\mathrm{k}_{\mathrm{s}}$ depend on the hydrodynamics of the feed and organic phases, respectively ${ }^{[36]}$.

In the case of NDSX operation, the overall mass transfer coefficient in the stripping module $\left(\mathrm{K}_{\mathrm{s}}\right)$ can be related to the individual mass transfer resistances by means of the next expression:

$$
\frac{1}{\mathrm{~K}_{\mathrm{s}}}=\frac{1}{\mathrm{k}_{\mathrm{s}}}+\frac{1}{\mathrm{k}_{\mathrm{m}}}+\frac{1}{\mathrm{k}_{\mathrm{st}} \mathrm{D}^{\prime}}
$$

where $\mathrm{k}_{\mathrm{s}}$ is the mass transfer coefficient in the organic feed solution, $\mathrm{k}_{\mathrm{m}}$ is the membrane mass transfer coefficient, $\mathrm{k}_{\mathrm{st}}$ is the mass transfer coefficient in the stripping solution and $\mathrm{D}^{\prime}$ is the distribution coefficient for stripping.

\section{SOME APPLICATIONS}

The broad spectrum of metal extraction which have been studied with SLMs includes noble metals, alkaline and earth alkaline metals, rare earth and radioactive metals and heavy and toxic metals. Whereas Table II summarize some uses of SLMs technologies in the removal of metals from different aqueous solutions, below are given more descriptive 
Table II. Selected published work on the use of supported liquid membranes technologies for metals removal from aqueous solutions

Tabla II. Algunas publicaciones recientes que emplean tecnologías de membranas líquidas soportadas en la extracción de metales de disoluciones acuosas

\begin{tabular}{|c|c|c|}
\hline Metal & Carrier & Reference \\
\hline \multirow[t]{7}{*}{$\mathrm{Co}(\mathrm{II})$} & DP-8R & {$[37]$} \\
\hline & triethanolamine & [38] \\
\hline & Cyanex 272 & [39] \\
\hline & LIX84I,TOPS-99,Cyanex272 & [40] \\
\hline & LIX860, DEHPA & [41] \\
\hline & Alamine 336 & [42] \\
\hline & Cyanex 272, DP-8R & [43] \\
\hline \multirow{4}{*}{$\mathrm{Ni}(\mathrm{II})$} & LIX 84I, DEHPA, LIX860I & [44] \\
\hline & triethanolamine & [45] \\
\hline & DEHPA, Cyanex 301, Cyanex 272, LIX 860-I & [46] \\
\hline & Acorga M5640, DP-8R & {$[47]$} \\
\hline \multirow[t]{3}{*}{$\mathrm{Cr}(\mathrm{III})$} & triethanolamine & [48] \\
\hline & trioctylmethylammonium chloride & [49] \\
\hline & DEHPA & {$[50]$} \\
\hline \multirow[t]{4}{*}{$\mathrm{Cr}(\mathrm{VI})$} & Cyanex 921 & [51] \\
\hline & Tertiary amines, Aliquat 336 & {$[52]$} \\
\hline & Aliquat 336 & [53] \\
\hline & Cyanex 923 & {$[54]$} \\
\hline \multirow[t]{5}{*}{$\mathrm{Cu}(\mathrm{II})$} & DEHPA & {$[55,56]$} \\
\hline & 8-hydroxyquinoline & {$[57]$} \\
\hline & LIX84I & [58] \\
\hline & LIX54, LIX84 & [59] \\
\hline & LIX984, LIX 984N & {$[60,61]$} \\
\hline \multirow[t]{2}{*}{$\mathrm{Ag}(\mathrm{I})$} & Macrocyclic polyethers & [62] \\
\hline & calix[4]pyrroles & [63] \\
\hline \multirow[t]{3}{*}{ Y(III) } & Aliquat 336, TBP & [64] \\
\hline & Cyanex 272, TBP & [65] \\
\hline & DEHPA & {$[66]$} \\
\hline \multirow[t]{3}{*}{$\mathrm{Cd}(\mathrm{II})$} & Cyanex 921, Cyanex 923 & [67] \\
\hline & organophosphorous acids & [68] \\
\hline & Cyanex 923 & [69] \\
\hline Radioactives & TBP & [70] \\
\hline $\mathrm{U}(\mathrm{VI})$ & Aliquat 336 & [71] \\
\hline Pu(IV) & $\mathrm{N}, \mathrm{N}, \mathrm{N}^{\prime} \mathrm{N}^{\prime}$-tetraoctyl diglicolamide & [72] \\
\hline \multirow{2}{*}{$\mathrm{Zn}(\mathrm{II})$} & DEHPA & [73] \\
\hline & TBP & {$[74]$} \\
\hline \multirow[t]{2}{*}{$\mathrm{V}(\mathrm{V})$} & Alamine 336, Cyanex 272 & [75] \\
\hline & tri-n-octylamine & [76] \\
\hline \multirow[t]{3}{*}{$\mathrm{Au}(\mathrm{I})$} & Primene JMT, Amberlite LA2, Hostarex A324 & {$[77]$} \\
\hline & Amberlite LA2 & [78] \\
\hline & Cyanex 923 & [79] \\
\hline \multirow[t]{4}{*}{$\mathrm{Au}(\mathrm{III})$} & Cyanex 923 & [79] \\
\hline & Alamine 304 & [80] \\
\hline & Cyanex 921 & [81] \\
\hline & Kelex 1000 & [82] \\
\hline $\mathrm{Pt}(\mathrm{IV})$ & Aliquat 336 & [83] \\
\hline Dy(III) & PC-88A & [84] \\
\hline
\end{tabular}


details of selected applications of these membrane technologies in this field.

A methodology for the selective transport of zinc(II) from cobalt(II) in sulphate solutions using a supported liquid membrane impregnated with DP-8R (di(2-ethylhexyl)phosphoric acid)) extractant has been described in the literature ${ }^{[85]}$. Different experimental conditions were investigated, stirring speed in feed and stripping, composition in stripping phase, kind and behavior of the organics phase diluents, $\mathrm{pH}$ in feed and concentration of the zinc in the feed and the carrier along operation of the membrane. The results demonstrated that the carrier DP-8R shows a good efficiency for zinc(II) transport and thus its separation from cobalt(II). However, the separation process can be improved by using a more effective membrane device such as hollow fiber modules. The best separation conditions were: (i) feed phase $\mathrm{pH}$ near $3 \pm 0.02$, [Co]/[Zn] molar concentration ratio near 22; (ii) stripping phase, $0.5 \mathrm{M}$ sulfuric acid; (iii) organic phase (membrane): DP-8R $10 \% \mathrm{v} / \mathrm{v}$ in Exxsol D100. The time life of the membrane also had been evaluated and demonstrated a stable mass transfer of zinc in a continuous operation of the membrane. When the $\mathrm{Zn}$ transport decreases, a re-impregnation of the membrane is enough to recover the transport ability. The mass transfer coefficient was $4.5 \times 10^{-3} \mathrm{~cm} \mathrm{~s}^{-1}$.

The best conditions for nickel(II) transport through a flat sheet supported liquid membrane using a mixture of Acorga M5640 (oxime derivative) and DP-8R (organophosphoric acid) as carrier are described in the literature ${ }^{[86]}$. This study concluded that the best conditions for nickel transport were: feed phase $\mathrm{pH}$ near to 4.0 , extractants mixture concentration of Acorga M5640 (10 \% v/v) and DP-8R (10 \% v/v) using an aliphatic solvent, the concentration of the stripping phase must be among $2.5 \times 10^{-3}$ and $1.0 \mathrm{~mol} \mathrm{~L}^{-1}$ sulphuric acid. Experimental results concluded that the mass transfer coefficient was $1.21 \times 10^{-3} \mathrm{~cm} \mathrm{~s}^{-1}$ and the limit layer thickness was $8.3 \times 10^{-3} \mathrm{~cm}$.

Among the various metals considered as hazardous for living organism, chromium (VI) is recognized to be one of the most dangerous due to its effect on development of cancer and non-cancer diseases. Liquid membrane technologies could be competitive to remove and/or recover chromium(IV) in the liquid effluents or wastewaters when the targeted species is present at low concentration in the aqueous solution.

The behavior of the phosphine oxides Cyanex 921 and Cyanex 923 in the facilititated transport of chromium(VI) from $\mathrm{HCl}$ solutions has been investigated ${ }^{[87]}$. For both carriers the transport of chromium (VI) is influenced by the variable studies, such as stirring speeds of the aqueous phases, membrane phase diluents, hydrochloric acid concentration in the source phase and chromium and carrier concentrations. Both carriers present the same affinity for chromium (VI) although Cyanex 923 seems to be more suitable when high concentrations of carrier are used in the organic phase. The separation of chromium (VI) from other metals presented in the source phase as well as the behaviour of phosphine oxides with respect to other neutral organophophorous derivatives TBP (tri-n-butylphosphate) and DBBP (dibuty butylphosphonate) were also investigated. The chromium (VI) is transported selectively before other metallic ions, cooper(II), nickel (II) and zinc(II), in the feed phase. The phoshine oxides seemed to transport chromium(VI) more efficiently than other neutral organophosphoric derivatives due to their higher electron-donor properties.

It had been investigated ${ }^{[88]}$ the chromium(VI) removal and concentration from ground waters using three different technological alternatives: anion-exchange resins, non-dispersive solvent extraction and emulsion pertraction. As carriers, for the two membrane technologies, either Aliquat 336 or Alamine 336 were used. Though anionexchange resins and emulsion pertraction lead to higher velocities in the elimination of chromium from the solution, and non-dispersive solvent extraction technology appeared more flexible and ease to operate, the three technologies showed the same concentration efficiencies.

The reduction of chromium(VI) to the chromium(III) state by hydrazine sulphate in the stripping process of chromium(VI)-loaded organic solutions had received attention. Various SLMs technologies were employed, such as flat-sheet supported liquid membranes, NDSX and pseudoemulsion based hollow fiber strip dispersion, in all the above investigations, the phosphine oxide Cyanex 923 was used as the carrier ${ }^{[89-91]}$.

The possibility of transport cadmium (II) from highly salinity medium across a flat sheet supported liquid membrane was explored by the use of organic solutions of Cyanex 923 in Solvesso 100 [92]. This solution was supported on a PVDF membrane, being water the strip solution. Permeability coefficients of metal increased when the $\mathrm{pH}$ of the feed solution decreased from 2 to 0.5 . It also increased when the concentration of carrier was also increased in the membrane phase, however, the permeation was dependent on the organic phase diluent but not on the metal concentration in the feed. The study concluded that Cyanex 923 in Solvesso 100 could be used effectively in the 
cadmium (II) transport in flat-sheet supported liquid membranes.

This same extractant was used to investigate the transport of cadmium(II) from neutral and acidic chloride media ${ }^{[93]}$. The investigation was carried out using two membrane technologies: flat-sheet supported liquid membrane and hollow fiber strip dispersion; in the latter, the rate of transport of cadmium(II) was faster in acidic chloride medium than in the neutral one.

By the use of non-dispersive solvent extraction with strip dispersion membrane technology and a double carrier (trialkyl-phopshine oxide and DEHPA) membrane phase, it was investigated the simultaneous removal and recovery of cadmium(II) and $\mathrm{CN}^{-}$from simulated electroplating rinse wastewater ${ }^{[94]}$. The transport velocities of both solutes is different, $\mathrm{CN}^{-}$higher than cadmium(II), when only the phosphine oxide is present in the organic phase, but the same transport rate is reached for both when DEHPA is added to the organic solution. It is claimed that the basic stripping solution containing $\mathrm{Cd}(\mathrm{CN})_{4}{ }^{2-}$ species can be again reused in the electroplating process.

The transport of cadmium through a PILM has also been considered using the quaternary ammonium salt Aliquat 336 as carrier. Various experimental conditions were investigated and it was concluded that the presence of chloride ions in the feed phase is necessary for the transport of cadmium(II) by this carrier, though there is not any apparent difference when the anion is present as $\mathrm{NaCl}$ or $\mathrm{HCl}$. Moreover, the system showed its selectivity against other metal-accompanying (nickel, cooper, paladium), cadmium in solutions from various sources ${ }^{[95]}$.

The removal and recovery of gold from aqueous solutions has received also attention, using different carriers and membrane technologies.

The commercially available extractant Cyanex 921 was investigated to be used for the carrierfacilitated transport of $\mathrm{Au}(\mathrm{CN})_{2}{ }^{-}$and $\mathrm{AuCl}_{4}{ }^{-}$ across a flat-sheet supported liquid membrane, and a model which describes the transport mechanism, consisting of diffusion through the feed side aqueous layer, a fast interfacial chemical reaction, and diffusion of carrier and metal complexes through the organic membrane was derived. For cyanide and chloride media, the mass transfer coefficients and the thickness of the aqueous boundary layer were estimated as $1.9 \times 10^{-3}$ and $3.9 \times 10^{-3} \mathrm{~cm} / \mathrm{s}$, and $5.3 \times 10^{-3}$ and $2.6 \times 10^{-3}$ $\mathrm{cm}$, respectively ${ }^{[96]}$.

The use of mixtures of extractants (mainly a solvation extractant plus another type of reagent) improves the extraction rate and the range of $\mathrm{pH}$ values in which $\mathrm{Au}(\mathrm{CN})_{2}{ }^{-}$can be effectively transported ${ }^{[97}$ and 98$]$. In the latter investigation, the used membrane technology was non-dispersive solvent extraction with one hollow fiber module and it was demonstrated that the use of a LIX $79+\mathrm{TOPO}$ mixture improves the rate of the precious metal recovery (more than $95 \%$ gold from a feed phase of $\mathrm{pH} 10.3$ ) over six times faster that when LIX 79 (a guanidine derivative) is used alone. These extractant mixtures also improves the $\mathrm{Au}(\mathrm{CN})_{2}{ }^{-}$selectivity over other metal-cyano complexes, i.e. $\mathrm{Zn}(\mathrm{CN})_{4}{ }^{2-}, \mathrm{Ag}(\mathrm{CN})_{2}^{-}, \mathrm{Cu}(\mathrm{CN})_{4}{ }^{3-}$ , etc., if present in the cyanide solution.

Pseudo-emulsion hollow fiber with strip dispersion technique was also used for gold recovery at alkaline $\mathrm{pH}$ values. In a recent investigation, LIX 79 dissolved in $\mathrm{n}$-heptane was employed as organic solution, and $\mathrm{NaOH}$ solutions were used as strip phase, both phases formed the pseudoemulsion which was pumped to the single hollow fiber module ${ }^{[99]}$.

In a very recent publication ${ }^{[100]}$, sonication was used to increase the transport rate of gold(III) with the quaternary ammonium salt Aliquat 336 as carrier. With sonication or ultrasound effects, the initial transport rate increased between 200 or $300 \%$ over that obtained without the use of this technology. Apparently, these results are due to the acoustic cavitation that sonication produces near the membrane/solution interface resulting in the elimination of the stagnant diffusion layer. The membrane technology used in the investigation was polymer inclusion membrane.

Whereas the use of PILMs had been reviewed in the literature ${ }^{[101]}$, a new approach to improve membrane performance had been published recently ${ }^{[102]}$. In this work, PILMs consisted in a mixture of cellulose triacetate, 2-nitrophenyl octyl ether and the macrocycle undecyl-aza-18crown- 6 as carrier. By the sequential membrane reconstitution, that is, after each transport run, the membranes were dissolved in methylene chloride and reformed as at first, the membrane showed a very little loss of permeability of the perrhenate anion under ten sequential runs.

The transport of silver ion through a supported liquid membrane containing DC18C6 (diicyclohexano18crown6), TOA (tri-n-octylamine) TBP (tributylphophate), TOPO (tri-n-octylphosphine oxide), as carriers in toluene, was investigated ${ }^{[103]}$. Various parameters were studied as binary carriers, carrier concentration, feed phase concentration, the nature and concentration of stripping agents in the stripping phase and flow rates of feed and stripping phases on transport efficiency. The maximum efficiency transport for $50 \mathrm{mg} / \mathrm{L} \mathrm{Ag}^{+}$ 
dissolved in $0.015 \mathrm{M} \mathrm{HNO}_{3}$ as feed was observed at flow rates of $50 \mathrm{ml} / \mathrm{min}$ in both phases, $0.05 \mathrm{M}$ DC18C6 in toluene as carrier solution, and 0.008 $\mathrm{M} \mathrm{Na}_{2} \mathrm{~S}_{2} \mathrm{O}_{3}$ as stripping solution. Optimum operation time was determined as $240 \mathrm{~min}$. Under these conditions, $94 \%$ of the silver ions were transported from the feed phase to the membrane phase, but the transport rate from the membrane phase to the stripping phase remained at approximately $81 \%$. The stripping phase prepared from $\mathrm{Na}_{2} \mathrm{~S}_{2} \mathrm{O}_{3}$ increases the transport efficiency of $\mathrm{Ag}^{+}$ions because $\left(\mathrm{S}_{2} \mathrm{O}_{3}\right)^{2-}$ ions formed a complex with the metal. When the stripping solution was prepared dissolving $\mathrm{Na}_{2} \mathrm{~S}_{2} \mathrm{O}_{3}$ in $\mathrm{NaOH}$ or $\mathrm{NH}_{4} \mathrm{OH}$, the transport efficiency decreased. A similar effect was observed using TBP, TOPO and TOA. Therefore, in order to improve metal transport efficiency, instead of using a second carrier, they concluded that is more useful to add a hydrophobic substance which reduces the viscosity of the liquid membrane. It was observed that, since the interaction between the two liquid phases was not possible, the ionic strength of the liquid phases does not affect the mass transport. It was pointed out that the membrane stability can be affected after 240 min operation time. It was also concluded that the transport of $\mathrm{Ag}^{+}$ions from the membrane phase to the stripping phase is not as rapid an efficient as the transportation from the feeding phase to the membrane phase because reaction taking place in the feed/membrane and the membrane/stripping interfaces occur at different reaction speeds, or the $\mathrm{Ag}+$ ions precipitated causing an accumulation in the membrane itself.

Plasticized cellulose triacetate membranes with dinonylnaphthalenesulfonic acid (DNNS) as the ion carrier containing 2 - nitrophenyl pentyl ether as the plasticizer, were used for competitive transport of Cs - 137; Sr - 90 and Co - 60 from sodium nitrate medium. The selectivity order of metal cations transported was found to be $\mathrm{Co}($ II $)>\operatorname{Cs}($ I $)>\operatorname{Sr}$ (II) ${ }^{[104]}$.

The selective separation of cesium (I) from radiotracers in acidic solutions, as feed phases, using supported liquid membrane using chlorinated cobalt dicarbollide (CCD) in phenyltrifluoromethyl sulphone (PTMS) as the carrier has been investigated ${ }^{[105]}$. Facilitated transport of cesium (I) was observed in about $3 \mathrm{~h}$ when $1 \mathrm{M} \mathrm{HNO}_{3}$ and $8 \mathrm{M} \mathrm{HNO}_{3}$ were used as feed and strip solutions, respectively. 0.025 M CCD in PTMS was used as the carrier phase. The selectivity studies were carried out using a mixture of radiotracers ${ }^{51} \mathrm{Cr}$, ${ }^{59} \mathrm{Fe},{ }^{99} \mathrm{Mo},{ }^{99 \mathrm{~m}} \mathrm{Tc},{ }^{106} \mathrm{Ru},{ }^{137} \mathrm{Cs},{ }^{152} \mathrm{Eu}$ and ${ }^{241} \mathrm{Am}$, and the results indicated the selective transport of cesium(I) with separation factor values greater than 100 . The reproducibility of the transport data was excellent when they are carried out in two successive transport experiments with freshly loaded carrier, but the stability of the membrane was poor, which restricts its long term use. The study concluded that the transport rates were influenced by the feed acidity and an increase in the feed acidity resulted in a sharp decrease in the permeability coefficient value. Increasing the carrier concentration decreased the transport rates. Strip dispersion technique could be used for longer stability.

The transport of yttrium (III) ions through micro-fiber supported liquid membranes in two stage processes namely source to membrane and membrane to receiving phase has received some attention ${ }^{[106]}$. The supported liquid membrane was impregnated with different concentrations of carrier, PC - 88A, in toluene. The transport of yttrium (III) ions depended on the $\mathrm{pH}$ of the source phase; the permeability of yttrium (III) increase with the increase in the $\mathrm{pH}$ from 1 to 6.5. The PC-88A concentration is also an important parameter in the transport of the ion: an increase in the PC $-88 \mathrm{~A}$ concentration increased the permeability value in the concentration range from $10^{-3}$ to $0.01 \mathrm{~mol} / \mathrm{L}$. Two channels fibers supported liquid membrane solvent extraction enhanced the ion transport in comparison with that of single channel fibers supported liquid membrane solvent extraction.

The transport behaviour of actinides, i.e. $\mathrm{Am}^{3+}$, $\mathrm{Cm}^{3+}$ and lanthanides: $\mathrm{La}^{3+}, \mathrm{Eu}^{3+}, \mathrm{Tb}^{3+}, \mathrm{Ho}^{3+}$, $\mathrm{Yb}^{3+}$ and $\mathrm{Lu}^{3+}$ through a supported liquid membrane containing the phosphinic acid Cyanex 301 dissolved in $n$-dodecane was investigated ${ }^{[107]}$. The strip solution was of $0.01 \mathrm{M}$ EDTA at $\mathrm{pH} 3.5$. The study concluded that it is possible the quantitative separation of $\mathrm{Am}^{3+}$ and $\mathrm{Cm}^{3+}$ from the lanthanides in 4 and 20 hours, respectively, while the separation factor values were in the range 108-4466.

The use of synthetic carrier (ionophore) for the separation of metal ions was investigated ${ }^{[108]}$. The effect of the structure of the ionophore on the separation of metal ions, using series of non-cyclic ionophores with different end groups and chain length $\left(R_{1}-R_{5}\right) .1 .5$ bis $(2-$ naphthyloxi $=-3$ oxapentane $\left(R_{1}\right), 1.8$ bis (2 - naphthyloxy) - 3,6 de - oxaoctane $\left(R_{2}\right), 1.11$ bis (2 - naphthyloxy)-3, 6,9 - tri-oxaundecane $\left(\mathrm{R}_{3}\right)$ 1.11-(dianthraquinoyloxy) 3, 6, 9 - trioxaundecane $\left(\mathrm{R}_{4}\right), 1.8$ (dianthraquinonyloxy) 3.6-dioxaoctane $\left(R_{5}\right)$ was described. These ionophores have been used in bulk liquid membrane and supported liquid membrane technologies in order to transport alkali $\left(\mathrm{Li}^{+}\right.$, $\left.\mathrm{Na}^{+}, \mathrm{K}^{+}\right)$and alkaline earth metal cations $\left(\mathrm{Ca}^{2+}\right.$, 
$\left.\mathrm{Mg}^{2+}\right)$. The supported liquid membrane consisted in a porous cellulose nitrate and an anion membrane support impregnated with the ionophore using chloroform as diluent. The results revealed that ionophores $\mathrm{R}_{1}, \mathrm{R}_{2}$ and $\mathrm{R}_{3}$ are better carriers for $\mathrm{K}^{+}$while $\mathrm{R}_{4}$ and $\mathrm{R}_{5}$ are better carriers for $\mathrm{Ca}^{2+}$. Among these ionophores, $R_{3}$ and $R_{4}$ are the best carriers for $\mathrm{K}^{+}$and $\mathrm{Ca}^{2+}$ ions. In SLM experiments using a cellulose nitrate membrane support, it was observed that naphthyl end group-bearing ionophores $\left(\mathrm{R}_{1}-\mathrm{R}_{3}\right)$ transported $\mathrm{Na}^{+}$better that $\mathrm{K}^{+}$, and anthraquinone-bearing ionophores $\left(\mathrm{R}_{4}\right.$ $\mathrm{R}_{5}$ ) transports $\mathrm{K}^{+}$selectively. On comparing the membrane support, the cellulose nitrate membrane is found better support for the transport of metal ions. The results suggested that due to the presence of different end groups and chain lengths the selectivity of non-cyclic ionophores towards metal ions is enhanced. This selectivity of ionophores may be suitable for application in ion selective electrodes and separation of metal ions.

The separation of metallic impurities $\mathrm{Zn}^{2+}$ and $\mathrm{Fe}^{3+}$ from trivalent chromium spent passivation baths used in the galvanic industry is a necessary step in the regeneration of the baths for their useful life extension. Selective liquid membranes have been used as efficient technologies to achieve this goal ${ }^{[109]}$. A Liqui-Cel hollow fiber membrane contactor was used to treat the spent bath with an emulsion phase constituted by an organic solution consisting of Cyanex 272, kerosene and 1-decanol and an acidic stripping phase. The study used real spent passivation baths, the metallic content of the feed was: $\mathrm{Cr}^{3+}, \mathrm{Zn}^{2+}$ and $\mathrm{Fe}^{3+}$. It was investigated the influence of different operational variables on the kinetics of the separation of zinc and chromium as $\mathrm{pH}$ of the feed, the initial zinc concentration, the carrier concentration in the liquid membrane and the type and concentration of acid, hydrochloric acid or sulphuric acid used as striping reagents. The study concluded that Cyanex 272 and sulphuric acid were the most suitable extraction and stripping agents, respectively.

A solid supported liquid membrane using a benzoylthiourea derivative (N-benzoyl-N', N'diheptadecylthiourea) had been used for the selective separation of mercury(II) from cadmium(II) and lead(II) in the $\mathrm{pH}$ range of 2 to $6 . \mathrm{A} 0.3 \mathrm{M}$ thiourea solution was used as strippant ${ }^{[110]}$. Mercury (II) is also transported selectively from arsenic(III) in $\mathrm{HCl}$ using tri-n-octylamine (TOA) as the carrier dissolved in toluene. The hollow fiber supported liquid membrane operation used $\mathrm{NaOH}$ as stripping solution $^{[111]}$. More recently, it had been described the use of polymer inclusion membranes containing Cyanex 471X (tri-isobutylphosphine sulphide) for
mercury(II) removal from $\mathrm{HCl}$ medium ${ }^{[12]}$. As stripping agent, a $0.05 \mathrm{M} \mathrm{NaCl}$ solution of $\mathrm{pH}$ 12.3 was used. Permeability values $\left(4.2 \times 10^{-3}\right.$ and $2.6 \times 10^{-3} \mathrm{~cm} / \mathrm{s}$ for feed and strip phases, respectively) were similar to those obtained in supported liquid membrane technique using the same carrier. The system presented a highly selectivity against the presence of many elements, i.e. cadmium, cooper, arsenic, zinc, etc.

The feasibility of a supported liquid membrane based mercury removal process using an environmentally benign diluent, such as coconut oil, has been investigated ${ }^{[113]}$. As carrier for mercury transport, trioctylamine was used, whereas the strip phase was a $0.3 \mathrm{M} \mathrm{NaOH}$ solution. Coconut oil shows better performance as diluent than other conventional ones such as dichloroethane or nheptane.

Despite the high hazardousness of arsenic, this element has received very little attention by the membrane community. Dibutylbutylphosphonate and the phosphine oxide Cyanex 921 were used as carriers for arsenic $(\mathrm{V})$ separation form sulphuric acid solutions ${ }^{[33}$ and 114$]$. Both carriers are classified as solvation extractants, and whereas the former studied PILM technology, in the latter case FSSLM was the technology used to investigate the transport of arsenic.

Several membrane technologies and carriers had been considered for the extraction of uranium(VI) from different aqueous media. The transport of radioactive metal ions by hollow fibersupported liquid membrane has been investigated ${ }^{[15]}$. The carrier employed was tributyl phosphate (TBP) diluted in kerosene and, as stripping solution, sodium hydroxide was used. $\mathrm{UO}_{2}{ }^{2+}$ species was extracted using TBP $5 \%(\mathrm{v} / \mathrm{v})$, rejecting thorium ions into raffinate, the maximum percentage of extraction for uranium being $67 \%$. A mathematical model was derived based on the extraction side of the liquid membrane system. These authors investigated the permeability for each concentration of $\mathrm{HNO}_{3}$ using the mass transfer theory. When the $\mathrm{HNO}_{3}$ concentration increases, more uranium ions are extracted; however, when the uranium and thorium concentrations in the feed solution increase, the percentage of extraction and stripping slightly decreased because the metal permeation decreases when the its concentration in the feed solution increases due to membrane fouling and concentration polarization.

Non-dispersive solvent extraction membrane technology, using an organic solution of $30 \% \mathrm{v} / \mathrm{v}$ TBP in $\mathrm{n}$-dodecane, was effectively used to extract uranium(VI) in macroconcentrations $(35 \mathrm{~g} / \mathrm{L})$ from $3 \mathrm{M}$ nitric acid feed solution, the strippant 
solution was $0.05 \mathrm{M}$ nitric acid. It was established to recover more than $90 \%$ of uranium(VI) from oxalate supernatant waste, which is often generated from nuclear chemical facilities ${ }^{[116]}$.

The recovery of uranium(VI) and plutonium(IV) from acidic supernatant wastes in oxalate medium from reprocessing plants was also investigated using PEFHSD technology ${ }^{[17]}$. These facilities produced oxalate supernatants during the plutonium precipitation using oxalic acid. The waste solution had the following composition: uranium(U): $5 \mathrm{mg} / \mathrm{dm}^{3}$, plutonium $(\mathrm{Pu}) 25 \mathrm{mg} / \mathrm{dm}^{3}$ ruthenium $\left(\mathrm{Ru}^{106}\right)$ $0,0032 \mathrm{mCi} / \mathrm{dm}^{3}$ : cesium $\left(\mathrm{Cs}^{137}\right) 0.003 \mathrm{~m} \mathrm{Ci} / \mathrm{dm}^{3}$, $3 \mathrm{M}$ nitric acid and $0.1 \mathrm{M} \mathrm{H}_{2} \mathrm{C}_{2} \mathrm{O}_{4}$. Using this membrane technology, it was investigated the recovery of these two nuclear elements from treated and non-treated wastes using TBP as carrier. The pseudo-emulsion was prepared by stirring at 600 $\mathrm{rpm}$, the organic/stripping solutions with a ratio of $1: 2$, being pumped to the outlet shell of the module fibers with a flow of $5 \mathrm{~L} / \mathrm{h}$, the uranium and plutonium recovery reached the $80 \%$ in nontreated waste and $90 \%$ in treated waste. The presence of fission products as ${ }^{137} \mathrm{Cs}$ and ${ }^{106} \mathrm{Ru}$ does not affect the transport of uranium. It is an indication that this technology is efficient for the recuperation of uranium(VI) and plutonium(IV) from supernatant oxalate waste.

Using a flat-sheet supported liquid membrane permeation cell, Joshi et al. ${ }^{[118]}$ investigated the transport of uranium(VI) and europium(III) from phosphoric acid feed. As carrier for metal transport, mixtures of DEHPA with various organophosphorous oxodonors dissolved in $\mathrm{n}$-dodecane were investigated. The mixture of DEHPA and tri-noctyl phosphine oxide is best suited for uranium(VI) transport from the aqueous feed with a good selectivity over europium(III), this selectivity is increased as the phosphoric acid concentration in the feed phase is increased from 1 to $6 \mathrm{M}$.

In a more recent study ${ }^{[119]}$, the transport of uranium(VI) from sulphate solutions using PILMs has been considered. Of the various carriers investigated, Alamine 336, Cyanex 272, Aliquat 336, TBP and DEHPA, the latter is the most effective for $\mathrm{UO}_{2}{ }^{2+}$ transport, the metal is stripped with a $4 \mathrm{M}$ sulphuric acid solution.

The recovery of copper used as homogeneous catalyst in wet peroxide oxidation (WPO) processes was investigated by a comparative study of two separation processes, EPP (pseudo emulsion in hollow fiber) and non dispersive solvent extraction ${ }^{[120]}$. The metal separation was improved by LIX $622 \mathrm{~N}$ as carrier and sulfuric acid as stripping phase. The study used a hollow fiber membrane module with an effective area of $1.4 \mathrm{~m}^{2}$. In both techniques, the decrease of copper concentration in feed is nearly the same. However, the main difference is that the concentration of copper in the stripping phase is 5.2 higher after four experimental cycles in EPP technology. The EPP extractions is advantageous because it offers practical and economic advantages over NDSX operation mainly due to the fact that the cost in membrane contactors operation is reduced to a half.

Ren et al. ${ }^{[121]}$, studied the $\mathrm{pH}$ effect on mass transfer of copper in a hollow fiber renewal liquid membrane. The system of $\mathrm{CuSO}_{4}$ was investigated in a buffer solution formed by acetate with D2EHPA in kerosene with acid aqueous solutions. They studied the effect of $\mathrm{pH}$ and the effect of acetate ion concentration in the feed and also the influence of acidity in the stripping phase. The results showed that the transfer flux increases when the $\mathrm{pH}$ in feed increases, reaching a maximum value at $\mathrm{pH}$ 4.4, and then decreases. Adding a buffer solution with a low concentration of acetate ion to the feed phase is enough to maintain the highest mass transfer flux. The influence of the stripping phase turned out to be of little significance. In order to achieve cupper extraction in this membrane, it sufficed to maintain a low hydrogen concentration in the stripping phase. The copper ions transfer fluxes were $\mathrm{Cl}^{-}>\mathrm{PO}_{4}{ }^{3-}>\mathrm{SO}_{4}{ }^{2-}>\mathrm{NO}_{3}{ }^{-}$. A mathematical model was also developed and the experimental data were fairly well reproduced by the model. This study demonstrated that $\mathrm{pH}$ in the feed influences the mass transfer in membrane.

A double strip dispersion hybrid liquid membrane was used in the simultaneous transport and separation of cooper(II), zinc(II) and cobalt(II) [122]. In the double membrane system, Acorga M5640-loaded membrane was placed between the left-hand and central compartments, whereas the mono(2 - ethylhexyl) 2 - ethylhexyl phosphonateloaded membrane was placed between the central and right-hand compartments of the cell. The central compartment contained the $\mathrm{Cu}-\mathrm{Zn}-\mathrm{Co}$ feed solution, whereas the left-hand compartment contained the dispersed strip solution of $3 \mathrm{M} \mathrm{HCl}$ in Acorga M5640/kerosene solution for cooper(II) recovery, and the right-hand compartment contained the dispersed strip solution of $2 \mathrm{M}$ sulphuric acid in the phosphonate/kerosene solution for zinc recovery. Optimum feed $\mathrm{pH}$ value for cooper(II) and zinc(II) transport with no cobalt(II) transport is in the $2-3$ range.

LIX 984N-C (mixture of oximes) was used as mobile carrier to investigate the transport of copper(II) in a tubular supported liquid membrane ${ }^{[123]}$. While various experimental conditions were studied, the copper feed solution 
passed through the tube side and the strippant (sulphuric acid) flowed through the shell side of the fiber. From experimental data, a relationship between Schmidt, Reynolds and Sherwood numbers was derived as $\mathrm{Sh}=8.4 \mathrm{Re}^{0.6} \mathrm{Sc}^{0.3}$.

Macrocycle and macromolecular compounds, i.e. crown ethers, ionizable lariat ethers, calixarenes, calyx crowns, as well as macrocycle polymers (i.e. cyclodextrins), and macromolecular compounds, i.e. acyclic polyethers, have been widely used as ion carriers in transport across various supported liquid membranes technologies for metal ions selective removal from different aqueous solutions ${ }^{[124]}$. The transport selective orders for the PIMs with calyx ${ }^{[4]}$ resorcinarenes derivatives was found to be $\mathrm{Pb}(\mathrm{II})>\mathrm{Cd}(\mathrm{II})>\mathrm{Zn}$ (II) ${ }^{[125]}$.

\section{CONCLUSIONS}

Supported liquid membranes are still a fascinating field of interest either for the academia, scientists and the industry. Several of the drawbacks associated with the first SLMs operational modes are being improved by the use of smart supported liquid membranes technologies and ionic liquids, and while their practical use is still not yet a reality, it is expected that in a near future supported liquid membranes will show their potential in the largescale treatment of metal-bearing liquid effluents. The future of these technologies seem to be highly exciting and promising.

\section{Acknowledgement}

To the CENIM (CSIC) for support and Dra I. García-Díaz the contract JAEDoc_09_00893, CSIC.

\section{REFERENCES}

[1] A.K. Bhattacharya, S.N. Mandal and S.K. Das, Chem. Eng. J. 123 (2006) 43-51.

[2] S.O. Lesmana, N. Febriana, F.E. Soetaredjo, J. Sunarso and S. Ismadji, Biochem. Eng. J. 44 (2009) 19-41.

[3] S. Strachan, Current Anaes, Crit. Care 21 (2006) 44-48.

[4] Y. Loubières, A. De Lassence, M. Bernier, A. Viellard-Baron, J.M. Schmitt, B. Page and F. Jardin, J. Toxicol-Clin. Toxicol. 37 (1999) 333-336.
[5] S.B. Goldhaber, Reg. Toxicol. Pharm. 38 (2003) 232-242.

[6] M. Casadevall and A. Kortenkam, Heavy Metals in the Environment, B. Sarkar (Ed.), Marcel Dekker, NY, USA, 2002, pp. 271-307.

[7] B. Kiran, A. Kaushik and C.P. Kaushik, J. Hazard. Mat. 141 (2007) 662-667.

[8] M. Navarro and C. Cabrera, Sci. Tot. Environ. 400 (2008) 115-141.

[9] K. Vijayaraghavan Palanivel and M. Velan, Biores. Technol. 97 (2006) 1411-1419.

[10] F.A.A. Al-Rub, M.H. El-Naas, I. Ashour and M. Al-Marzouqi, Proc. Biochem. 41 (2006) 457-464.

[11] C.E. Borba, R. Guirardello, E.A. Silva, M.T. Veit and C.R.G. Tavare, Biochem. Eng. J. 30 (2006) 184-1912.

[12] L. Den, Y. Su, H. Su, X. Wang and X. Zhu, Adsorption 2 (2006) 267-277.

[13] F.S.J. Godt, C. Grosse-Siestrup, V. Esche, P. Brandenburg, A. Reich and D.A. Groneberg, J. Occup. Medicine Toxicol. 1 (2006) $1-6$.

[14] F.J. Alguacil and M.A. Villegas, Rev. Metal. Madrid 38 (2002) 45-55.

[15] N.M. Kocherginsky, Q. Yiang and L. Seelam, Sep. Purif. Technol. 53 (2007) 171-177.

[16] F.J.Alguacil, M.Alonso, F.Lopez and A.LopezDelgado, Chemosphere 72 (2008) 684-689.

[17] R.L. Gardas and J.A.P. Coutinho, Fluid Phase Equilibrium 266 (2008) 195-201.

[18] D. Han and K. Ho Row, Molecules 15 (2010) 2405-2426.

[19] L. Duchet, J.C. Legeay, D. Carrié, L. Paquin and J.J. Van den Eynde, Tetrahedon 66 (2010), 968-994.

[20] M.V.B. Zanoni, E.I. Rogers, C. Hardacre and R.G. Compton, Anal. Chim. Acta 659 (2010) 115-121.

[21] N. Fontanals, S. Ronka, F. Borrull, A.W. Trochimczuk and R.M. Marcé, Talanta 80 (2009) 250-256.

[22] F.-T. Li, R.-H. Liu, J.-H. Wen, D.-S. Zhao, Z.M. Min and Y. Liu, Green Chem. 11 (2009) 883-888.

[23] J.M. Reyna-Gonzalex, A.A.J. Torriero, A.I. Siriwardana, I.M. Burgar and A.M. Bond, Anal. Chem. 82 (2010), 7691-7698.

[24] A.P. de los Rios, F.J. Hernández-Fernandez, L.J. Lozano, S. Sanchez, J.I. Moreno and C. Godinez, J. Chem. Eng. Data 55 (2010) 605-608.

[25] V. Gallardo, R. Navarro, I. Saucedo, M. Avila and E. Guibal, Sep. Sci. Technol. 43 (2008) 2434-2459. 
[26] M.H. Mallah, F. Shemirani and M.G. Maragheh, Environ. Sci. Technol. 43 (2009) 1947-1951.

[27] F.J. Alguacil, M. Alonso, F.A. Lopez, A.LopezDelgado, I. Padilla and H. Tayibi, Chem. Eng. J. 157 (2010) 366-372.

[28] F.J. Alguacil, M. Alonso, F.A. Lopez and A. Lopez-Delgado, Environ. Sci. Technol. 44 (2010) 7504-7508.

[29] P.R. Danesi, J. Membr. Sci. 20 (1984) 231-248.

[30] N.A. D’Elia, L. Dahuron and E.L.Cussler, J. Membr. Sci. 29 (1986) 309-319.

[31] G. Zuo, S. Orecchio and M. Muhammed, Sep. Sci. Technol. 31 (1996) 1597-1613.

[32] F.J. Alguacil and M. Alonso, Environ. Sci. Technol. 39 (2005) 2389-2393.

[33] M.E. Martinez Perez, J.A. Reyes-Aguilera, T.I. Saucedo, M.P. Gonzalez, R. Navarro and M. Avila-Rodriguez, J. Membr. Sci. 302 (2007) 119-126.

[34] L. Pei, B. Yao and C. Zhang, Sep. Purif. Technol. 65 (2009) 220-227.

[35] E. Bringas, M.F. San Roman, J.A. Irabien and I. Ortiz, J. Chem. Technol. Biotechnol. 84 (2009) 1583-1614.

[36] A. Kumar, R. Haddad, F.J. Alguacil and A.M. Sastre, J. Membr. Sci. 248 (2005) 1-14.

[37] F.J. Alguacil, Hydrometallurgy 65 (2002) 914.

[38] N. Bukhari, A. Chaudry and M. Mahar, J. Membr. Sci. 234 (2004) 157-165.

[39] S. Basudev, J. Jinki, L. Jae-Cun and L. GaeHo, J. Membr. Sci. 288 (2007) 139-148.

[40] P.K. Prhi and K. Sarangi, Sep. Purif. Technol. 59 (2008) 169-174.

[41] K. Verbeken, B. Vanheule, L. Pinoy and M. Vehaege, J. Chem. Technol. Biotechnol. 84 (2009) 711-715.

[42] A. Sürückü, V. Eyüpoglu and O. Tutkun, Desalination 250 (2010) 1155-1156.

[43] S. Basudev, J. Jinki, Y. Kyoungken and L. JaeCun, Hydrometallurgy 101 (2010) 20-27.

[44] I. Van de Voorde, L. Pinoy and R.F. de Ketelaere, J. Membr. Sci. 234 (2004) 11-21.

[45] N. Bukhari, M. Ashraf Chaudry and M. Mazhar, J. Membr. Sci. 283 (2006) 182-189.

[46] A.W. Lothongkum, Y. Khemglad, N. Usomboon and U. Pancharoen, J. All. Comp. 476 (2009) 940-949.

[47] R. Gonzalez, A. Cerpa and F.J. Alguacil, Chemosphere 81 (2010) 1164-1169.

[48] M. Ashraf Chaudry, B. Naheed, M. Mazhar and A. Wajiha, Sep. Purif. Technol. 55 (2007) 292-299.
[49] F.J. Alguacil, M. Alonso, F.A. Lopez and A. Lopez-Delgado, Sep. Purif. Technol. 66 (2009) 586-590.

[50] K. Ochromiowicz and W. Apostoluk, Sep. Purif. Technol. 72 (2010) 112-117.

[51] F.J. Alguacil, C. Caravaca and M.I. Martin, J. Chem. Technol. Biotechnol. 78 (2003) 1048 1053.

[52] C.A. Kozlowski and W. Walkowiak, J. Membr. Sci .266 (2005) 143-150.

[53] B. Galan, M. Calzada and I. Ortiz, Chem. Eng. J. 124 (2006) 71-79.

[54] G. Arslan, A. Tor, H. Muslu, M. Ozmen, I. Akin, Y. Cengeloglu and M. Ersoz, J. Membr. Sci. 337 (2009) 224-231.

[55] D.-Y. Zuo, B.-K. Zhu, S.-H. Wang and Y.Y. Xu, Polym. Adv. Technol. 16 (2005) 738 743.

[56] R. Molinari, P. Argurio and T. Poerio, Sep. Purif. Technol. 70 (2009) 166-172.

[57] N. Parthasarathy, M. Pelletier and J. Buffle, J. Membr. Sci. 355 (2010) 78-84.

[58] A.O. Adebayo and K. Sarangi, Sep. Purif. Technol. 63 (2008) 392-399.

[59] Q. Yiang, J. Jiang, T.-S. Chung and N.M. Kocherginsky, AIChE J. 52 (2006) 3266-3277.

[60] N.A. Osman, Hydrometallurgy 77 (2005) 269-277.

[61] W. Zhang, C. Cui, Z. Ren, Y. Dai and H. Meng, Chem. Eng. J. 157 (2010) 230-237.

[62] O. Arous, H. Kerdjoudj and P. Seta, J. Membr. Sci. 241 (2004) 177-185.

[63] A.A. Amiri, A. Safavi, A.R. Hasaninejad, H. Shrghi and M. Shamsipur, J. Membr. Sci. 325 (2008) 295-300.

[64] A.G. Gaikwad, Chem. Biochem. Eng. Q. 17 (4) (2003) 327-334.

[65] P. Ramakul, T. Supajaroon, T. Prapasawat, U. Pancharoen and A.W. Lothongkum. J. Ind. Eng. Chem. 15 (2009) 224-228.

[66] P.W. Naik, P. Jagasia, P.S. Dhami, P.V. Achthan, S.C. Tripathi, S.K. Munski, P.K. Dey and M. Venkatesh, Sep. Sci. Technol. 45 (2010) 554-561.

[67] FJ. Alguacil and M. Alonso, Hydrometallurgy 74 (2004) 195-202.

[68] R.S. Juang, H.C. Kao and W.H. Wu, J. Chem. Technol. Biotechnol. 79 (2004) 140-147.

[69] A.M. Sastre, F.J. Alguacil, M. Alonso, F. Lopez and A. Lopez-Delgado, Solvent Extr.Ion Exch. 26 (2008) 192-207.

[70] P. Ramakul, T. Prapasawad, U. Pancharoen and W. Pattaveekongka, J. Chinese Inst. Chem. Eng. 38 (2007) 489-494. 
[71] P.K. Mohapatra, D.S. Lakshmi, D. Mohan and V.K. Manchanda, Sep. Purif. Technol. 51 (2006) 24-30.

[72] S. Panja, P.K. Mohapatra, P. Kandwal, S.C. Tripathi and V.K. Manchanda, Desalination 262 (2010) 57-63.

[73] D. He, X. Luo, C. Yang, M. Ma and Y. Wan, Desalination 194 (2006) 40-51.

[74] H. Samaniego, M.F. San Roman and I.Ortiz, Ind. Eng. Chem. Res. 46 (2007) 907-912.

[75] L.J. Lozano, C. Godinez and F.J. Alguacil, Hydrometallurgy 80 (2005) 196-202.

[76] M. Ashraf Chaudry, N. Bukhari, M. Mazhar and F. Tazeen, Sep. Purif. Technol. 54 (2007) 227-233.

[77] F.J. Alguacil, Rev. Metal. Madrid 38 (2002) 419-425.

[78] F.J. Alguacil and M. Alonso, Gold Bulletin 38 (2005) 68-72.

[79] F.J. Alguacil and M.I. Martin, Sep. Sci. Technol. 38 (2003) 2055-2069.

[80] F.J. Alguacil, Solvent Extr. Ion Exch. 21 (2003) 841-852.

[81] F.J. Alguacil, Hydrometallurgy 71 (2004) 363-369.

[82] E. Rodriguez de San Miguel, A.V. GarduñoGarcia, M.E. Nuñez-Gaytan, J.C. Aguilar and J. de Gyves, J. Membr. Sci. 307 (2008) 1-9.

[83] C. Fontas, R. Tayeb, M. Dhahbi, E. Gaudichet, F. Thominette, P. Roy, K. i Steenkeste. M.P. Fontaine-Aupart, S. Tingry, E. Tronel-Peyroz and P. Seta, J. Membr. Sci. 290 (2007) 62-72.

[84] L. Pei, B. Yao and X. Fu, J. Rare Earths 27 (2009) 447-456.

[85] F.J. Alguacil and M. Alonso, Sep. Purif. Technol. 41 (2005) 179-184.

[86] F.J. Alguacil, M. Alonso and A. LópezDelgado, J. Braz Chem.Soc. 17 (2006) 839843.

[87] F.J. Alguacil, A. López-Delgado, M. Alonso and A.M. Sastre, Chemosphere 57 (2004) 813. 819.

[88] B. Galan, D. Castañeda and I. Ortiz, Water Res. 39 (2005) 4317-4324.

[89] F.J. Alguacil and M. Alonso, Environ. Sci. Technol. 37 (2003) 1043-1047.

[90] F.J. Alguacil, M. Alonso, F.A. Lopez, A. Lopez-Delgado and I. Padilla, Environ. Sci. Technol. 43 (2009) 7718-7722.

[91] J.V. Sonawane, A.K. Pabby and A.M. Sastre, J. Hazard. Mat. 174 (2010) 541-547.

[92] F.J. Alguacil and H. Tayibi, Desalination 180 (2005) 181-187.
[93] N.S. Rathore, A. Leopold, A.K. Pabby, A. Fortuny, M.T. Coll and A.M. Sastre, Hydrometallurgy 96 (2009) 81-87.

[94] D. He, S. Gu and M. Ma, J. Membr. Sci. 305 (2007) 36-47.

[95] N. Pont, V. Salvado and C. Fontas, J. Membr. Sci. 318 (2008) 340-345.

[96] F.J. Alguacil, M. Alonso and A.M. Sastre, J. Membr. Sci. 252 (2005) 237-244.

[97] F.J. Alguacil and M. Alonso. Hydrometallurgy 74 (2004) 157-163.

[98] A.K. Pabby, R. Haddad, F.J. Alguacil and A.M. Sastre, Chem. Eng. J. 100 (2004) $11-22$.

[99] J.V. Sonawane, A.K. Pabby and A.M. Sastre, AIChE J. 54 (2008) 453-463.

[100] Y.Y.N. Bonggotgetsakul, M. Ashokkumar, R.W. Cattrall and S.D. Kolev, J. Membr. Sci. (2010), doi.10.1016/j.memsci.2020.09.013.

[101] L.D. Nghiem, P. Mornane, I.D. Potter, J.M. Perera, R.W. Cattrall and S.D. Kolev, J. Membr. Sci. 281 (2006) 7-41.

[102] J.D. Lamb, J.N. West, D.P. Shaha and J.C. Johnson, J. Membr. Sci. doi:10.1016/ j.memsci. 2010.09.019.

[103] S. Altin, Y. Yildirim and A. Altin, Hydrometallurgy 103 (2010) 144-149.

[104] C.A. Kozlowski, W. Walkoviak and W. Pellowski, Desalination 242 (2009) 29-37.

[105] P.K. Mohapatra, A. Bhattacharyya and V.K. Manchanda, J. Hazard. Mat. 181 (2010) 679-685.

[106] A.G. Gaikwad and A.M. Rajput, J. Rare Earths 28 (2010) 1-6.

[107] A. Bahattacharyya, P.K. Mohapatra and V.K. Manchanda, Sep. Purif. Technol. 50 (2006) 278-281.

[108] J. Tomar, A. Awasthy and U. Sharma, Desalination 232 (2008) 102-109.

[109] A. Urtiaga, E. Bringas, R. Mediavilla and I. Ortiz. J. Membr. Sci. 356 (2010) 88-95.

[110] C. Fontas, M. Hidalgo, V. Salvado and E. Antico, Anal. Chim. Acta 547 (2005) 255-261.

[111] S. Sangtumrong, P. Ramakul, C. Satayaprasart, U. Pancharoen and A.W. Lothongkum, J. Ind. Eng. Chem. 13 (2007) 751-756.

[112] F.E. Mercader-Trejo, E. Rodriguez de San Miguel and J. de Gyves, J. Chem. Technol. Biotechnol. 84 (2009) 1323-1330.

[113] K. Chakrabarty, P. Saha and A.K. Ghoshal, J. Membr. Sci. 350 (2010) 395-401.

[114] M.L. Ballinas, E. Rodriguez de San Miguel, M.T.J. Rodriguez, O. Silva, M.Muñoz and J. de Gyves, Environ. Sci. Technol. 38 (2004) 886-891. 
[115] P. Ramakul, T. Prapasawad, U. Pancharoen and W. Pattaveekongka, J. Chinese Inst. Chem. Eng. 38 (2007) 489-494.

[116] S.K. Gupta, N.S. Rathore, J.V.Sonawane, A.K. Pabby, P. Janardan, R.D. Changrani and P.K. Dey, J. Membr. Sci. 300 (2007) 131-136.

[117] S.C. Roy, J.V. Sonawane, N.S. Rathore, A.K. Pabby, P. Janardan. R.D. Changrani, P.K. Dey and S.R. Bharadwaj, Sep. Sci. Technol. 43 (2008) 3305-3332.

[118] J.M. Joshi, P.N. Pathak, A.K. Pandey and V.K. Manchanda, Hydrometallurgy 96 (2009) 117-122.

[119] A.M. St John, R.W. Cattrall and S.D. Kolev, J. Membr. Sci. 364 (2010) 354-361.
[120] A. Urtiaga, M.J. Abellan, J.A. Irabien and I. Ortiz, J. Membr. Sci. 257 (2005) 161-170.

[121] Z. Ren, W. Zhang, Y. Dai, Y. Yang and Z. Hao, Ind. Eng. Chem. Res. 47 (2008) 4256-4262.

[122] X. Luo, D. He, M. Ma, Sep. Sci. Technol. 45 (2010) 2130-2140.

[123] S. Makaka, M. Aziz and A. Nesbin, J. Mining Metal. Section B: Metallurgy 46 (2010) 67-73.

[124] W. Walkowiak and C.A. Kozlowski, Desali nation 240 (2009) 186-197.

[125] N. Benosmane, S.M. Hamdi, M. Hamdi and B. Boutemeur, Sep. Purif. Technol. 65 (2009) 211-219. 